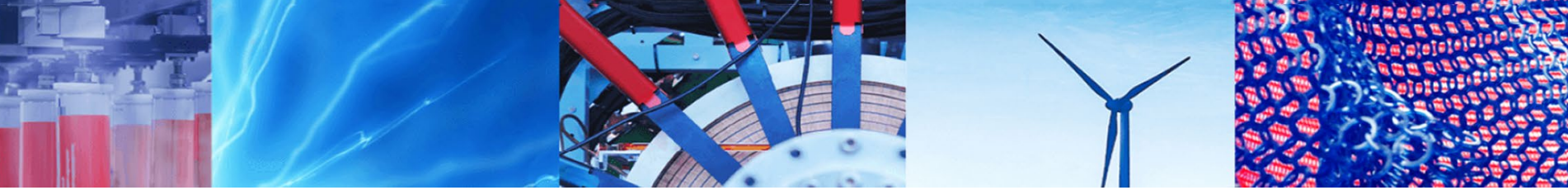

Review Paper

\title{
A review on environmental selenium issues
}

\author{
Getachew Dagnew Gebreeyessus ${ }^{1}\left[\mathbb{D} \cdot\right.$ Feleke Zewge $^{2}$
}

(c) Springer Nature Switzerland AG 2018

\begin{abstract}
Selenium is an essential element since it is necessary for metabolism and is also toxic to the living things if it is consumed above the desirable limit. For instance, up to $40 \mu \mathrm{g}$ per $\mathrm{d}$ of dietary selenium is essential for human health; however, consumption of a little over $400 \mu \mathrm{g}$ per $\mathrm{d}$ could result in adverse physiological problems. In the environment, selenium occurs in different species; of which selenate and selenite are its most toxic forms accounting for $95 \%$ of selenium toxicity. Though, selenium fortification is important for normal human physiology in selenium deficient environments, it needs to be minimized or removed from selenium rich environmental media. Thus, its quantification is significantly important to control per limit. Currently there is advancement in the detection and quantification of selenium in environmental including the use of a Hydride Generating Atomic Absorption Spectroscopy. Due to the excess occurrences of selenium in different locations the removal techniques from geogenic or anthropogenic sources include microbial metabolism, phytoremediation, sorption, membrane separation, coagulation, ion exchange and catalytic reduction. Most of all, the microbial removal is applied in drinking water supply and in selenium recovery from wastewater sludge. Though current selenium removal from sorption studies reported better efficiency, phytoremediation appears attractive due to its field scale application advantage. However, the fate of selenium following phytoremediation remains unaddressed.
\end{abstract}

Keywords Selenium · Toxicity · Occurrence · Environment

\section{Introduction}

Both geogenic and anthropogenic activities govern selenium in the environment. Environmental biogeochemical conditions control the bioavailability and the nature of selenium species [1-5]. Geogenic pollution of groundwater is referred to as the natural occurrence of elevated concentration of certain elements in groundwater having negative health effects [6]. In fact, selenium is listed among the minor constituents in geogenic water pollution $(0.1-100 \mu \mathrm{g} / \mathrm{l})$. Moreover, the narrow tolerance limit of selenium brings serious concerns through deficiency as well as toxicity in the biological and environmental systems. Toxicity generally results when certain ions are taken up with the soil-water and accumulate in some organs of plants and animals. Though geogenic selenium contamination is a concern for toxicity from drinking water, plants are the main source of dietary selenium [7].

By elemental category, selenium is nonmetal and sometimes it is considered as trace element. Geographically, it is widely distributed throughout the world, but only in small quantities. It is more commonly found together with the sulfides as the selenides in the ores of such metals as iron, lead, silver, and copper [8]. Selenium salts are toxic in large amounts, but trace amounts are necessary for cellular function in many organisms, including all animals $[9,10]$.

Fortified selenium is an ingredient in many multivitamins and other dietary supplements, including infant formula in many countries. In human, low dietary selenium intakes are associated with health disorders including oxidative stress-related conditions, reduced fertility and immune functions and an increased risk of cancers. For

\footnotetext{
$\triangle$ Getachew Dagnew Gebreeyessus, getachewdagn@yahoo.com | ${ }^{1}$ Department of Urban Environmental Management, Kotebe Metropolitan University, P.O. Box 31248, Addis Ababa, Ethiopia. ${ }^{2}$ African Center of Excellence for Water Management, Addis Ababa University, P.O. Box 1176, Addis Ababa, Ethiopia.
} 
that purpose the daily intake in the diets differ worldwide, for UK adult female and male 60 and $75 \mu \mathrm{gSe} / \mathrm{d}$ respectively are expected while for the World Health Organization (WHO), it is $10 \mu \mathrm{g} / \mathrm{l}$ in water $[11,12]$. Contrasting the former, a study in Burundi of Africa that reported risk in deficiency with average intake of $17 \mu \mathrm{gSe} / \mathrm{d}$ from diet [13]. In fact, intake depends on age and sex [14]. However, selenium turns out to be toxic in low margin beyond limit causing hair and nail loss, cancer and even death as detailed later in the toxicity section of this article.

Until recently a lot of research have been done on selenium either as toxic or as nutrient. As of the middle of the 1990 s approximately 100,000 research papers had been published on the topic of selenium since it was discovered by the Swedish chemist Jons Jakob Berzelius in 1817 [5]. However, it is only recently that its geogenic contamination and bioremediation, selenium recovery as resource, selenium detection methods, and occurrence as well as distribution especially in the African continent have begun to be discovered.

Therefore, the objective of this mini review is to comprehensively present the nature, geochemistry, toxicity, biochemistry, detection and quantification methods reported on selenium in the past researches. Further it systematically reports the remediation techniques applied to selenium at various scales and shows fillable gaps for further research.

\section{Selenium property and toxicity}

\subsection{Physicochemical properties of selenium}

The physical, atomic properties and periodic table position of selenium is shown in figure one. Selenium appears

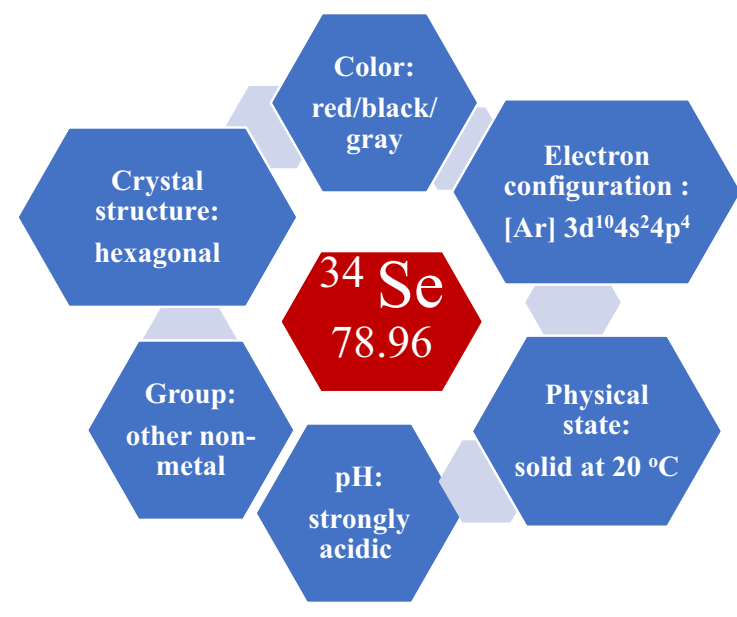

Fig. 1 Appearance and properties of selenium as black and red allotropes (Fig. 1). It was found out long ago that it's electrical resistance is greater in the light than in the dark $[15,16]$. Analogous to the behavior of other chalcogens, selenium forms hydrogen selenide, $\mathrm{H}_{2} \mathrm{Se}$. It is a strongly odiferous, toxic, and colorless gas. It is more acidic than $\mathrm{H}_{2} \mathrm{~S}$. In solution it ionizes into $\mathrm{HSe}^{-}$[17].

Chemically, selenium is reactive towards many reagents allowing their incorporation into organic compounds. Further, symmetric or non-symmetric diselenides are often used as starting materials for the preparation of more complex chalcogen-containing derivatives [8]. Selenium also forms complexes with heavy metals including cadmium, sparing its biological effects as reported earlier [18].

Although the element selenium itself is not toxic, many of its compounds are extremely toxic. For instance, $\mathrm{H}_{2} \mathrm{Se}$ is a colorless, foul-smelling gas that is poisonous. It also forms selenides with most metals (for example, aluminum selenide, cadmium selenide, and sodium selenide). In groundwater, selenium exists in the dissolved forms of $\mathrm{Se}$ $(+\mathrm{VI})$, Se (+IV), and Se (-II). Selenium (+IV) is more toxic due to its higher bioavailability.

\subsection{Selenium in plants: toxic dose, symptoms and distribution}

Though debatable, it has been reported that selenium is not an essential element to plants but it can be toxic to them [19]. Generally, the plant toxicity of inorganic selenium, namely selenate and selenite anions, is higher than the organic forms of selenium depending on three major factors. Absorption of the anions by the roots and the subsequent translocation into other parts of the plant is the first factor. Secondly, the metabolism of the anions into organic forms in the cell and thirdly the interference of cellular biochemical reaction in plants due to selenium metabolite of which replacing the role of sulfur [20] and protein functions are worth to mention.

The distribution of selenium in plants is all over it, from the root to its aerial parts. However, there is dissimilarity between selenate and selenite in distribution. Furthermore, the toxicity and tolerance character vary among plants [21]. The later mainly depends on their ability to divert selenium away from the accumulation of selenocysteine and selenomethionine that ranges from $2 \mathrm{mg} / \mathrm{kg}$ in non-accumulators, such as rice, and $330 \mathrm{mg} / \mathrm{kg}$ in white clover, to several thousands of $\mathrm{mg} / \mathrm{kg}$ in the accumulator Astragalus bisulcatus. For instance, in non-accumulator's selenium toxicity occurs under about $10-100 \mathrm{mg} \mathrm{Se} / \mathrm{kg}$ of dry weight (DW). Toxicity occurs mostly due to the accumulation of selenium in the plant tissues. The characteristic symptoms due to selenium toxicity includes stunting, chlorosis, and fading of leaves, interfering with chlorophyl combination and nitrate accumulation that is generally 
assumed to occur from selenium levels higher than $1 \mathrm{mg} /$ $\mathrm{kg}$ [22-25].

\subsection{Selenium in animals: toxic dose and health symptoms}

Earlier, selenium is identified as micronutrient for bacteria, mammals and birds earlier; however, it is now recognized as a problem if it is consumed in excess. A case in point is the alkali disease in livestock that was observed in the American great plains since then concern on chronic and acute selenosis raised [26]. Based on testes on laboratory animals, the minimum lethal dose of selenium as acute toxicity in rabbits, rats, and cats was between 1.5 and $3.0 \mathrm{mg} / \mathrm{kg}$ body weight as sodium selenite or selenate and irrespective of the mode of entry of the compound into their body. During acute toxicity, laboratory animals showed garlicky breath odor, vomiting, dyspnea, tetanic spasms, and death from respiratory failure accompanied by pathological changes. Chronically, a selenium dietary dose of 4-5 parts per million (ppm) proved to cause growth inhibition [27].

In farm animal's selenium acute toxicity occurs due to the ingestion of seleniferous accumulator plants or due to excess supplements with following signs of severe distress that include labored breathing, abnormal movement and posture, and prostration and diarrhea, and even death in few hours $[27,28]$. The chronic selenosis also known as alkali disease occurs in animals consuming grains containing $5-40 \mathrm{mg} \mathrm{Se} / \mathrm{kg}$ over a period of several weeks or months with signs and symptoms that include liver cirrhosis, lameness, hoof malformations, loss of hair, and emaciation [29].

The determination of selenium level in animal tissues and organ has been investigated along with its metabolism in sheep. Findings revealed that the accumulation of selenium varies among the different organs, the liver being the highest accumulator. Further the share of selenium through enzymatic extracted in the form of amino acid compounds was $40 \%$ [30]. In a related earlier study in Burundi of Africa, kidney of goats and cows is found to be the accumulator organ for selenium ranging 994-1852 ng/g wet weight for goats and 1056-1801 ng/g wet weight for cows. This finding has relevance to note the safety and adequacy of nutrients for people in developing countries; however South Africa is the only African state on the list of seleniferous areas which rather mentioned Africa in relation to selenium deficiencies in crops and livestock as reported in a recent study [31,32].

Selenium toxicity in animals or plants edible to human is a primary concern since bio-magnification of selenium starts when animals consume plant biomass that has impounded large amounts of selenium and get magnified in food chains that can involve aquatic selenium pollution $[33,34]$. Besides, due to irrigation run-off concentrations of selenium tend to be very high in aquatic organisms in many areas. Thus, the bioaccumulation potential of selenium can further cause toxicity to the natural ecosystem. When animals absorb or accumulate extremely high concentrations of selenium it can cause reproductive failure and birth defects [35-37].

\subsection{Selenium in humans with epidemiological perspective}

Water, food and air in decreasing order are identified earlier as source of human toxicity from selenium [38]. Moreover, drinking water sources remains to be a concern in geogenic selenium contamination. For instance, in many French regions, geogenic sedimentary sources of selenium were identified as responsible for the selenium concentrations exceeding the European limit in many wells designated to produce drinking water [36]. Selenium toxicity is prevalent in 1000 ha in Hoshiarpur and Nawanshahar of Nigerian districts where about 11 and $4 \%$ of groundwater samples were found unfit for drinking and irrigation purposes, respectively [35].

Selenium carries the narrowest range between its nutritional deficiency $(<40 \mu \mathrm{g} / \mathrm{d})$ and toxicity $(>400 \mu \mathrm{g} / \mathrm{d})$ with respect to the daily intake [17] (Table 1). Selenate and selenite have an oxidant mode of action in living organisms and are very toxic. In humans, the toxic effects of longterm high level environmental selenium exposure are manifested in dermatological effects, nails, hair and liver problems [39].

Selenium exposure can result in either acute or chronic health problems. An acute exposure is explained by selenium neurotoxicity while the chronic exposure is explained by the toxic effect on endocrine function especially in the synthesis of thyroid hormones and if the dose exposed is relatively lower [39, 40]. For instance, a report from China indicated that clinical and biochemical signs occur at a daily intake above $0.8 \mathrm{mg}$. Conversely, inadequate concentration of selenium in Chinese diet is a cause for Keshan disease which is the degeneration of articular cartilage between joints, thyroid disease and different forms of cancer $[26,38]$.

To get the nutrient benefit from selenium diet fortification became an alternative. Care should be taken as in product labeling; otherwise, toxicity outbreak is inevitable as exhibited in the identified outbreak due to the selenium in a liquid dietary supplement in a certain town in the United States. Based on epidemiological observation, the median estimated dose of selenium consumed was 41 $749 \mu \mathrm{g} / \mathrm{d}$ with frequently reported symptoms that include diarrhea, fatigue, hair loss, joint pain, nail discoloration or 
Table 1 Commonly accepted drinking water quality guidelines for selenium $[62,63]$

Constituent Drinking water standards recommended by Bureau of Indian Standard (BIS) and the World Health Organization (WHO) $(\mathrm{mg} / \mathrm{l})$

$$
\text { BIS (2012) }
$$

Acceptable limit Permissible limit in the absence of alternative source

Selenium
No relaxation
WHO (2011)

Guideline values

0.01
Undesirable effect when present beyond acceptable limit in drinking water
Very low selenium status in humans has
been associated with juvenile, multifo-
cal myocarditis and chondrodystrophy.
Very high selenium status causes
gastrointestinal disturbance, skin dis-
coloration and tooth decay brittleness, and nausea [41, 42]. Nevertheless, acute toxicity problem is rare due to diet diversity despite the rising concern over environmental selenium contamination in the United States.

Elsewhere in New Zealand and Venezuela, acute selenosis was observed due to the selenium rich food consumption [43]. In a related fact the daily intake of Venezuelan children with clinical signs was estimated to be about $0.7 \mathrm{mg}$. Effects on synthesis of a liver protein were also seen in a small group of patients with rheumatoid arthritis given selenium at a rate of $0.25 \mathrm{mg} / \mathrm{d}$ in addition to selenium intake through food. No clinical or biochemical signs of selenium toxicity were reported in a group of 142 persons with a mean daily intake of $0.24 \mathrm{mg}$ (maximum $0.72 \mathrm{mg}$ ) from food [44].

\section{Environmental fate of selenium}

Selenium in the whole environment can be either from natural or anthropogenic sources forming cycles between them (Fig. 2). The natural bases of selenium include the weathering of selenium-containing rocks and soils and volcanic eruptions [45]. Anthropogenically, selenium pollution in the environment is hugely contributed by the coal mining and the use of selenium rich fossil fuels in industries that can account $40 \%$ of selenium in air as well as the aquatic systems that resulted in wastewater discharge limit of $5 \mu \mathrm{g} \mathrm{Se/I}[34,37]$. In that regard, selenium contamination in groundwater and surface water in numerous river basins worldwide has become a critical issue in recent decades $[46,47]$, especially due to the geogenic contamination. In order to foresee the mineralization, mobilization, and toxicity extent of selenium to plants, animals and human in natural systems understanding of its oxidation state is important. In geologic formations, selenium transformation and speciation depend on the presence of nitrate $\left(\mathrm{NO}_{3}\right)$, organic materials and clay content, $\mathrm{pH}$ and carbonates/bicarbonates for mobility and hence the risk associated [48-51].

Selenium concentrations in soils vary widely, from 5 to $1,200,000 \mu \mathrm{g} / \mathrm{kg}$, being higher in soils of more recent volcanic origins. It is normally found in concentrations ranging $50-90 \mu \mathrm{g} / \mathrm{kg}$ of soil, but higher concentrations can be associated with some volcanic, sedimentary and carbonate rocks. Selenium occurs in environmental soils in several forms, according to its possible oxidation states: selenides $\left(\mathrm{Se}^{2-}\right)$, amorphous or polymeric elemental selenium $\left(\mathrm{Se}^{0}\right)$, selenites $\left(\mathrm{Se}^{4+}\right)$ and selenates $\left(\mathrm{Se}^{6+}\right)$ (IPCS, 1987; UK EGVM, 2002).

Regarding selenium speciation, acidic and reducing conditions reduce inorganic selenites to elemental selenium, whereas alkaline and oxidizing conditions favor the formation of selenates in the environment. Since selenites and selenates are both soluble in water, selenium is leached from oxic alkaline soils that favor its oxidation. In contrast, the elemental and selenides forms are insoluble in water; consequently, selenium inclines to be retained in wet and anoxic soils. Thus, selenium in alkaline soils is accessible by plants; however, the availability of selenium in acidic soils inclines to be restricted by the adsorption of selenites and selenates to iron and aluminum oxide soils (NRC 1983).

Based on the species extraction using $0.1 \mathrm{~mol} / \mathrm{I} \mathrm{NaOH}$, all the four selenium compounds are present as anionic species based on their pKa values at a $\mathrm{pH}$ of 13 . Being in state of dissolution or precipitation and absorption or desorption, selenium is present in almost all soils, particularly in irrigated agricultural aquifer systems underlain by or adjacent to shale formations containing seleno-pyrite where $\mathrm{SeO}_{4}$ can be released through autotrophic reduction of $\mathrm{O}_{2}$ or $\mathrm{NO}_{3}$ [52] (Eqs. 1a, 1b).

$$
\begin{aligned}
& 2 \mathrm{FeSe}_{x} \mathrm{~S}_{2-x}+7 \mathrm{O}_{2}+2 \mathrm{H}_{2} \mathrm{O} \rightarrow 2 \mathrm{Fe}^{2+}+2 x \mathrm{SeO}_{4}^{2-} \\
& +(4-2 \mathrm{X}) \mathrm{SO}_{4}^{2-}+4 \mathrm{H}^{+}
\end{aligned}
$$




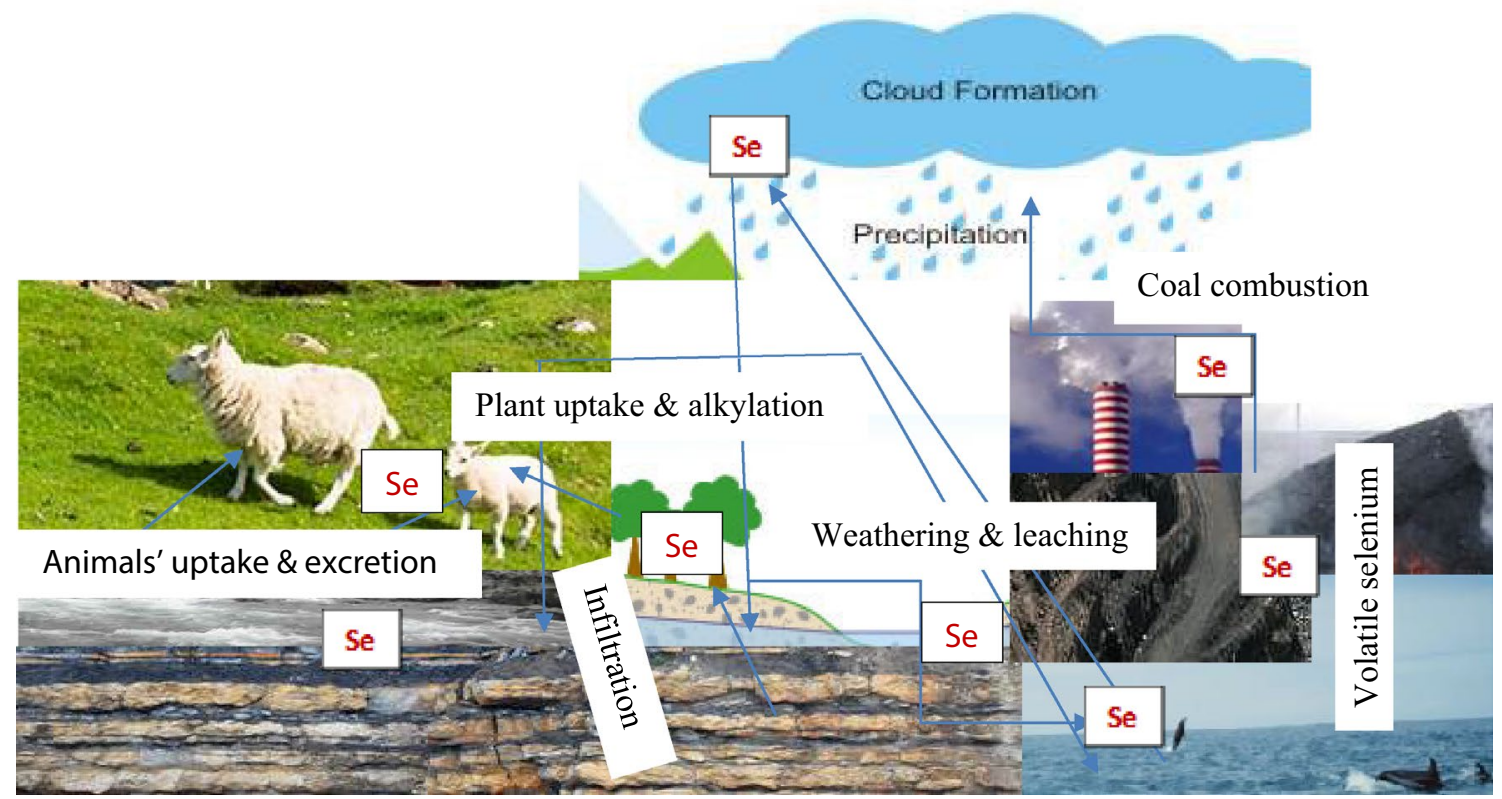

Fig. 2 Selenium cycle in the environment near the surface of the earth. (Redrawn from [1] with permission from John Wiley and Sons. $\odot$ 2016 WILEY-VCH Verlag GmbH \& Co. KGaA, Weinheim)

$$
\begin{aligned}
& 5 \mathrm{FeSe}_{x} \mathrm{~S}_{2-x}+14 \mathrm{NO}_{3}^{-}+4 \mathrm{H}^{+} \rightarrow 5 \mathrm{Fe}^{2+}+5 x \mathrm{SeO}_{4}^{2-} \\
& +(10-5 \mathrm{X}) \mathrm{SO}_{4}^{2-}+7 \mathrm{~N}_{2}+2 \mathrm{H}_{2} \mathrm{O}
\end{aligned}
$$

Selenate is mobilized in oxidizing condition and is interfered by reducing condition as well as adsorption. Irrigation and agriculture are associated with Se mobility. In addition, selenium is subject to cycling in the plant-soil system similar to other nutrients such as nitrogen $(\mathrm{N})$, phosphorus (P), and sulfur (S).

Selenium mobility and risk of toxicity are not limited to physico-chemical phenomena. Microbially-mediated chemical reduction reactions reduce $\mathrm{SeO}_{4}$ to $\mathrm{SeO}_{3}$ [Eq. (2a)] and $\mathrm{SeO}_{3}$ to either immobile $\mathrm{Se}^{0}$ [Eq. (2b)] or mobile selenomethionine (SeMet) suggesting the possible mitigation pathways for $\mathrm{SeO}_{4}$. Almost all of the selenium removal techniques include reduction of $\mathrm{SeO}_{4}$ to $\mathrm{SeO}_{3}, \mathrm{Se}$, or SeMet that in most case it is inhibited by the presence of $\mathrm{O}_{2}$ and $\mathrm{NO}_{3}$ which act as electron acceptors. However, it is suggested that there is a concentration of $\mathrm{NO}_{3}$ at which $\mathrm{NO}_{3}$ reduction and $\mathrm{SeO}_{4}$ reduction can even occur simultaneously [53].

$$
\begin{aligned}
& \mathrm{CH}_{2} \mathrm{O}+2 \mathrm{SeO}_{4}^{2-} \rightarrow \mathrm{CO}_{2}+2 \mathrm{SeO}_{3}^{2-}+\mathrm{H}_{2} \mathrm{O} \\
& \mathrm{CH}_{2} \mathrm{O}+\mathrm{SeO}_{3}^{2-}+2 \mathrm{H}^{+} \rightarrow \mathrm{CO}_{2}+\mathrm{Se}^{0}+2 \mathrm{H}_{2} \mathrm{O}
\end{aligned}
$$

The risk of selenium toxicity in the environment is affected by its mobility. In that regard experimental study by Bassil and co-workers revealed that even though the less fraction (10\%) of selenium was mobilizable, $70 \%$ of it was Se (IV) which is the most soluble species [54]. Environmentally, the selenium pool exists much in the lithosphere followed by the fossil fuel deposits and oceans (Fig. 3), thus, its geochemistry and hence the associated risk is also affected by climate variability [55].

\section{Geochemistry of selenium and bioavailability}

Worldwide the occurrence of selenium is irregular. Selenium is widely distributed in the environment, but its natural geogenic concentration level is generally below $1 \mu \mathrm{g} / 1$ in natural waters or below $1000 \mu \mathrm{g} / \mathrm{kg}$ in rocks and soils provided that anthropogenic influences are only moderate [56]. Their distribution ranges from selenium deficit regions like the United Kingdom with a daily intake of $<55 \mu \mathrm{g}$ to selenium rich regions like Canada with a daily intake between 100 and $200 \mu \mathrm{g}$. Again, the intake amount is explained on the fact that selenium soil concentration is determined in many countries. Countries like Ireland, parts of the United State and India are in the toxic range while Yugoslav and Finland are deficient (Fig. 4).

Following its spatial variation, the daily selenium intake varies worldwide by country. For some regions of the world, selenium occurrence is scarce and raises issue of nutrient limitations rather than issue of toxicity. Accordingly, different countries attempted to trace its occurrence and dietary implication, whether its removal or fortification would be needed in their water supply scheme or not. Thus, selenium in Africa appears to be within limit, if not nutrient fortification is essential for most countries (Fig. 5). 

millions of $\mathrm{kg}$ ) in various environmental pools worldwide. (Reprinted by permission from Springer-Verlag Berlin Heidelberg, Hydrogeol J [5]. @ Springer-Verlag Berlin Heidelberg 2016)
Fig. 3 Mass of selenium (in

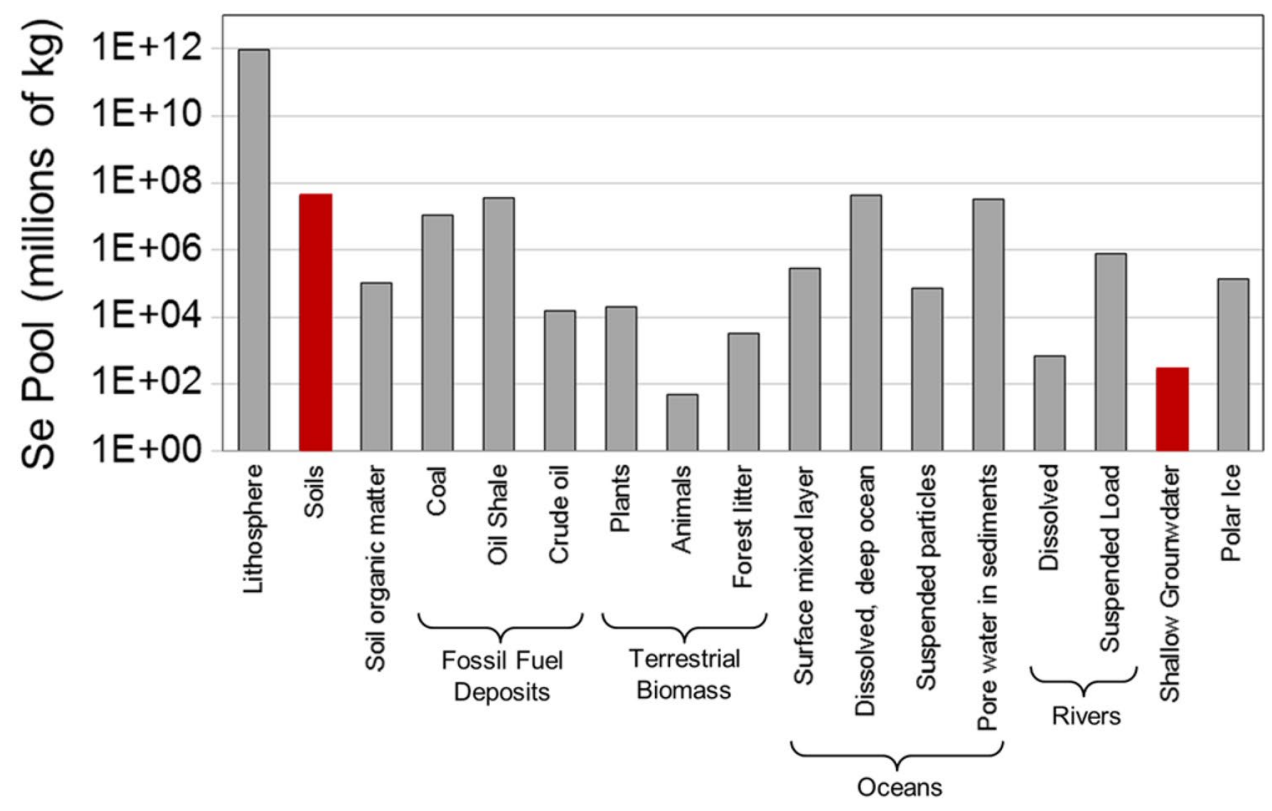

Interestingly, recent studies report the importance of selenium in reducing the risk of arsenicosis due to selenium mediation [57,58], arsenic hit regions may even need selenium supplement to tackle arsenicosis. Selenium is widely distributed in the environment with average occurrence of $0.09 \mathrm{ppm}$ and its occurrence or distribution has been investigated in rocks, soils, minerals, groundwater and surface water [27].

\subsection{Selenium in rocks}

High selenium concentrations are associated with some phosphatic rocks, organic-rich black shales, coals, and sulfide mineralization, whereas most other rock types contain very low concentrations. Selenium deficient environments are far more widespread than seleniumcontaining ones. However, it should be recalled that health outcomes are not only dependent on the total selenium content of rocks and soils but also on the amount of selenium taken up into plants and animals as bioavailable selenium from its cycle in the environment (Fig. 2) [32].

\subsection{Selenium occurrence and distribution in minerals}

Selenium naturally occurs in a number of inorganic forms, namely selenide, selenate, and selenite, but these minerals are rare. Selenium rarely occurs in its elemental state or as pure ore compounds in the earth's crust. It is found in metal sulfide ores, where it partially replaces the sulfur. Likewise, the organic compounds of selenium and

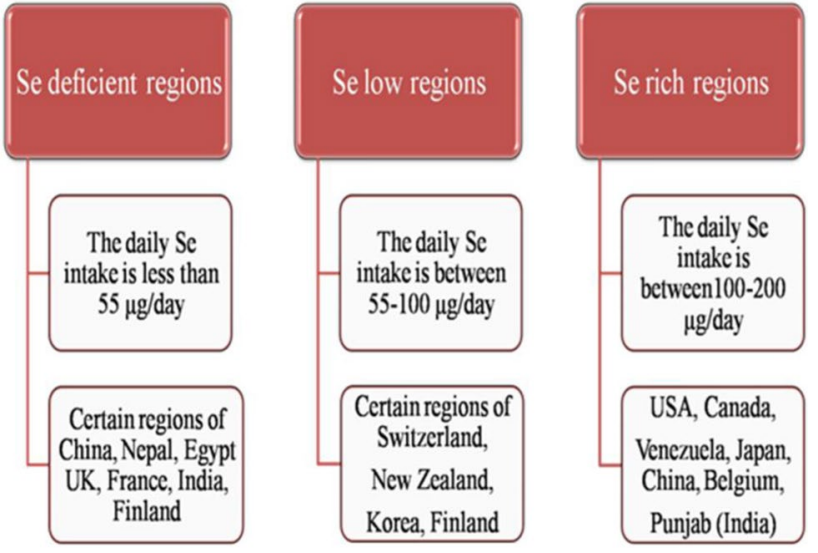

Fig. 4 Outline of occurrence of selenium in different regions of the world as selenium-deficient, selenium-low and selenium-rich regions [7]

tellurium are known since the late nineteenth century [8]. Selenium is found as a major constituent of 40 minerals and a minor component of 37 others, chiefly sulfides [27].

Based on a reconnaissance survey conducted in South Africa by K Sami and AL Druzynski, selenium is not related to rock-forming silicates, and is most abundant in sulfide minerals, such as galena (commonly $0-15$ ppm), arsenopyrite (42-57 ppm), pyrrhotite (5-63 ppm), marcasite (0-11 ppm), chalcopyrite (commonly between 10 and $50 \mathrm{ppm}$ ), pyrite (commonly between 0 and $50 \mathrm{ppm}$ ), and sphalerite (commonly between 10 and 50 ppm, can be as high as 900 ppm) [60]. 

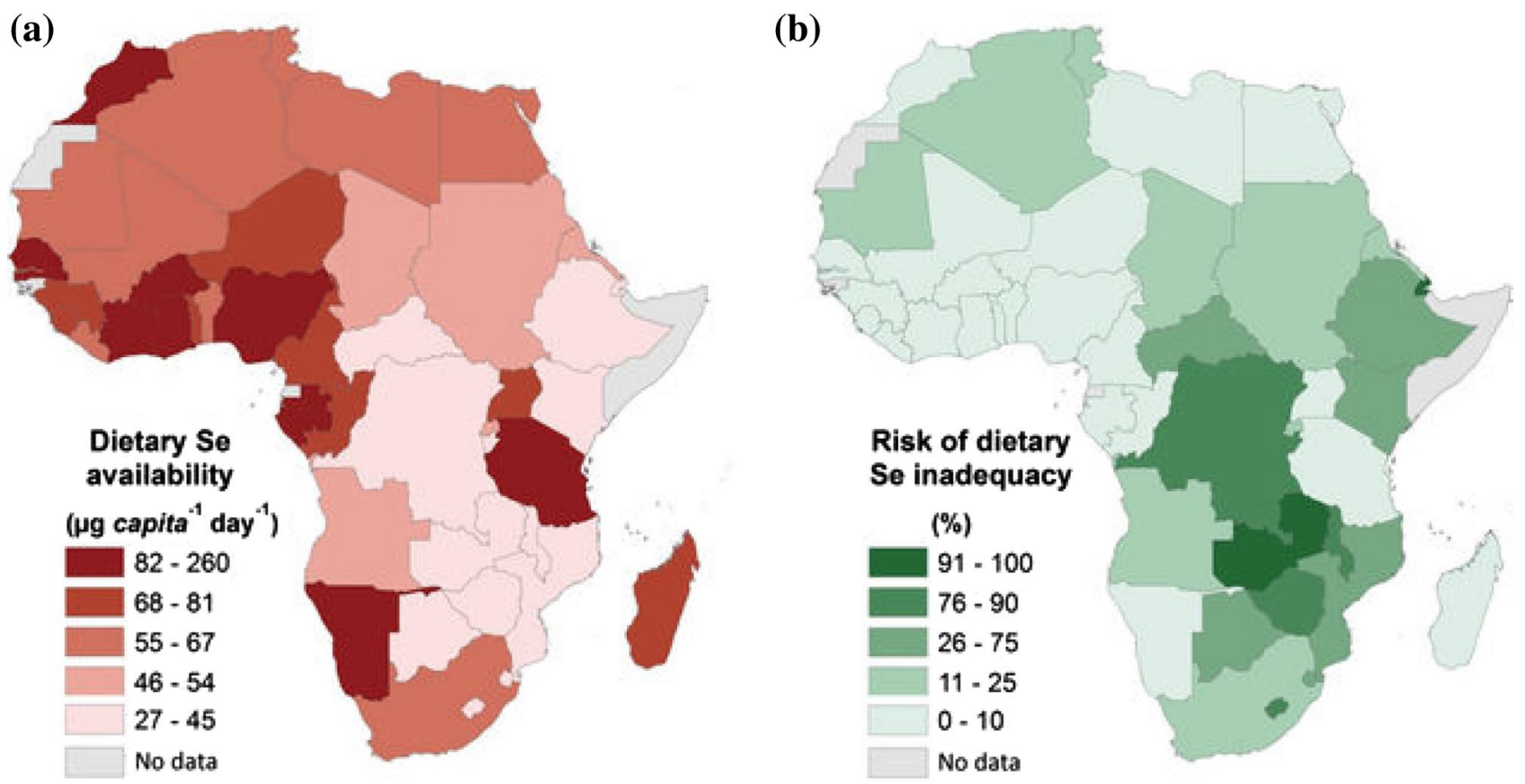

Fig. 5 Dietary selenium availability and risk of inadequacy in Africa. (Source: [59])

\subsection{Selenium occurrence and distribution in soils}

The occurrence of selenium in different soils is mainly a reflection of the underlying rock as well as practice of irrigation with selenium rich groundwater. The soluble selenite and selenate species in soil enter into plant metabolism; however, leaching and formation of insoluble complex by selenite accounted for losses into the environment like other insoluble selenium species. Most soils showed a selenium content ranging between 0.1 and $0.2 \mathrm{ppm}$ while a maximum of $100 \mathrm{ppm}$ is detected in the United States. However irregular concentrations have been measured in different regions of the world including China. In that regard sedimentary rocks are most reported contributor to soil selenium and to plants. In relation to that predicting selenium mobility in soils is proposed as researchable area in order to address either deficiency or toxicity issues [10, 27, 51]. In fact, selenium is also present in air though it is detected to nano scale concentration especially in urban air [43].

\subsection{Selenium occurrence and distribution in groundwater and surface water}

Based on reports, selenium content in natural water exists in the range of $0.1-400 \mu \mathrm{g} / \mathrm{l}$ and sometimes reaching up to $6000 \mu \mathrm{g} / \mathrm{l}$. In such water bodies the predominant species are those biogeochemically relevant selenite and selenate from mobility and bioavailability points of views [61].
Selenium poisoning may result from water systems whenever new agricultural runoff flow through a normally dry, undeveloped lands. This process leaches natural soluble selenium compounds (such as selenates) into the water, which may then be concentrated in emerging wetlands. Selenium pollution of waterways also occurs when selenium is leached from coal flue ash, mining and metal smelting, crude oil processing, and landfill.

Recently issues of selenium water contamination are associated with selenium biochemical risks. For instance, from the 210 ground water samples taken in Nigeria, selenium concentration of $7.33 \pm 6.22-46.3 \pm 22.4 \mu \mathrm{g} / \mathrm{L}$ is reported following the needed assessment vis-à-vis risk of geogenic contamination which is almost greater than that of WHO's limit of $10 \mu \mathrm{g} / \mathrm{l}$ [35] (Table 1). The distribution of selenium was fairly uniform in the samples studied in different locations that suggested the influence of geogenic factors. More than that, in some parts of the United States dark-gray shale sampled from 51 locations in Colorado, New Mexico, and Utah, many of the groundwater samples were found saline with selenium concentration of $1000 \mu \mathrm{g} / \mathrm{l}$ [2] which is 100 times beyond the limit recommended by the WHO.

Locally, selenium occurrence is rarely checked including the status in groundwater. There is a report noting that selenium content in Ethiopia is generally low, though a concentration of 15-7600 $\mu \mathrm{g} / \mathrm{l}$ [64] is reported for ground waters of the rift valley region of the country; and the median values being lower for spring and surface water 
sources. Yet, this range of selenium concentration is over the limit value set by WHO. However, selenium health effect, either deficiency or toxicity, is not known or unreported. Moreover, that same region is a concern for other geogenic water contamination in which fluoride is the most explored one [65-67].

The selenium enrichment in groundwater may be caused by the contact with sedimentary formations. The selenium behavior as function of $\mathrm{pH}$ was similar in the ultrapure water that can determine its leaching behavior (Fig. 6) $[36,68]$. Thus, medium-range oxidation-reduction potential (ORP) and neutral $\mathrm{pH}$ are critical conditions for the toxic selenium to exist or to become dominant as species.

\subsection{Reactivity and mobility conditions of selenium species}

In the environment $\mathrm{pH}$ and reduction conditions play role in selenium species and mobility. Acidic and reducing conditions reduce inorganic selenites to elemental selenium, whereas alkaline and oxidizing conditions favor the formation of selenates as described earlier. Consequently, since selenites and selenates are soluble in water, selenium is leached from well-aerated alkaline soils that favors its oxidation. Conversely, elemental selenium and selenides are insoluble in water; therefore, selenium tends to be sorbed to wet and poorly aerated soils. Thus, reducing conditions of the environment favor those forms. As a result, selenium in alkaline soils is available for uptake by plants, whereas the availability of selenium in acidic soils tends to be limited by the adsorption of selenites and selenates to iron and aluminum oxide soils (Figs. 7, 8) [5, 69]. Further, temperature, moisture, the concentrations of water-soluble selenium, climate condition, organic matter content and microbial activity also determine selenium mobility.

As an anthropogenic activity, agriculture does not only increase the selenium content in soil but it can also increase selenium concentrations in surface water, as selenium is brought along with irrigation drainage water [70]. In that regard, factors controlling selenium release into the groundwater system, soluble $\mathrm{Na}-$ and $\mathrm{Mg}-\mathrm{SO}_{4}$ salts represent the primary mobile reservoir of selenium in the Mancos Shale and associated alluvium, with only minor contributions from relatively insoluble gypsum. These salts are more prevalent in alluvium than Mancos Shale, and thus the alluvium represents a potential large source of readily mobilized selenium, which has been reported in other irrigated alluvial valleys particularly in the Western United States and China [71].

Generally, selenium species typically have greater reactivity towards oxidants and attract oxidants comparably greater than sulfur that is determined by their scavenging

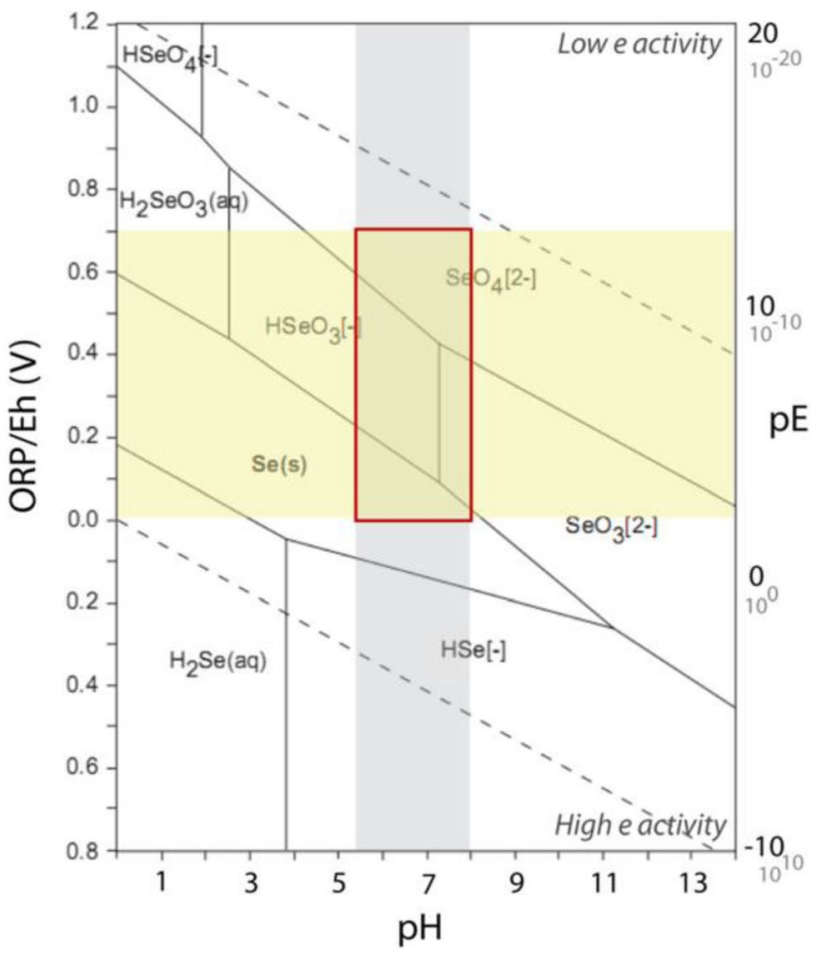

Fig. 6 Phase diagram of selenium speciation. (Reprinted with permission from Springer-Verlag Berlin Heidelberg, Hydrogeol J [5]. (c) Springer-Verlag Berlin Heidelberg 2016)

efficient on oxidants including hypochlorous acid, especially in living systems. Such reactivity of selenium brings implications of pros and cons in living system $[72,73]$. Besides, its acid forms in the activation of $\pi$-bonds in diynyl esters giving to conjugate structures are recently reported $[74,75]$.

\section{The selenium biochemistry}

In the environment whereby inorganic selenium is transformed into volatile forms including $\left(\mathrm{CH}_{3}\right)_{2} \mathrm{Se}$ by the microbial action of fungi and plants, organic selenium is found in biotic systems [61]. Selenium metabolism is found in all domains of life, such as in bacteria, archaea, and eukarya and viruses. The chalcogen, selenium, plays an important role in animals, plants and microbes and their enzymes [76] especially after the major finding that uracil guanine and adenosine (UGA) termination codon is used to direct the covalent insertion of selenocysteine. Selenocysteine is viewed as the 21 st amino acid by many scientists in terms of ribosome-mediated protein synthesis-into certain selenium-dependent enzymes [77, 78]. Selenium is incorporated into amino acids, such as cysteine, and then into selenium-containing proteins. Three types of redox enzymes that contain selenium in the form of 
Fig. 7 Selenium species and transformation pathways between the species in a soilgroundwater-shale system; dissolution, organic incorporation, and $\mathbf{b}$ the succession of terminal e-accepting processes in a soil-groundwater system, showing the chemical reduction of $\mathrm{SeO}_{4}$ to $\mathrm{SeO}_{3}$ only after $\mathrm{O}_{2}$ and $\mathrm{NO}_{3}$ have been reduced [5] tion, volatilization, precipita-

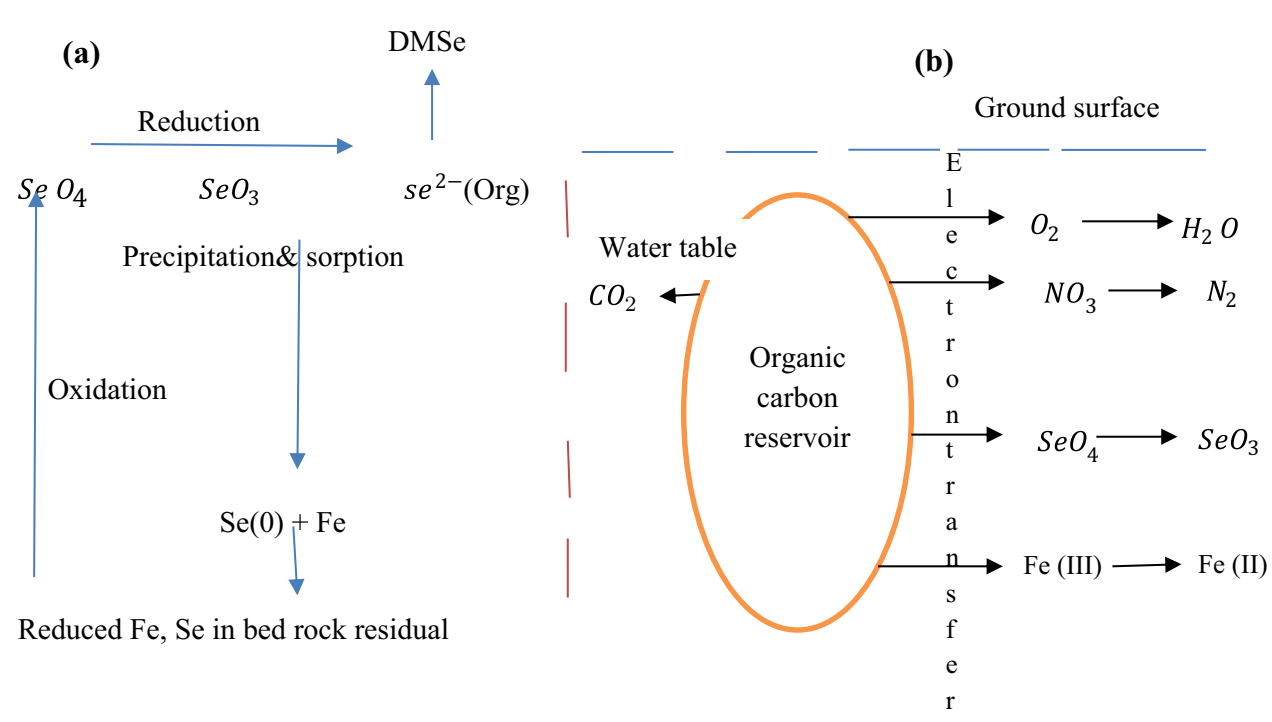

Fig. 8 Selenium cycle in nature and role of organisms

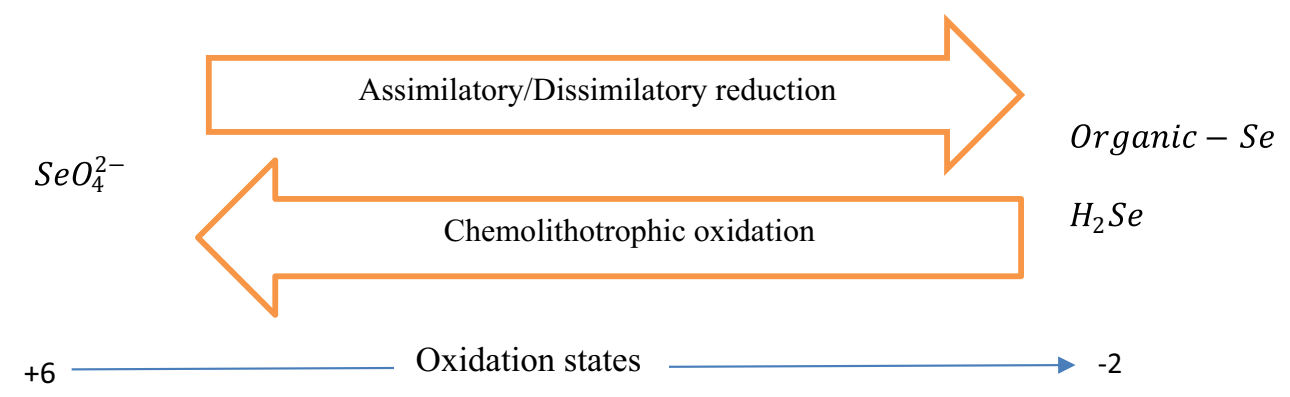

selenocysteine have been isolated so far and they are characterized from bacterial sources, whereas only one, glutathione peroxidase, is known in mammals [79].

In nature the selenium cycle (Fig. 8) is partially maintained by selenium reducing bacteria (SeRB). The role of selenium cycling is played partly by the microorganisms that use selenate and selenite as terminal electron acceptors whose selenium biomineralization mechanisms gave ways to selenium environmental biotechnological applications [80].

In bacteria and archaea, selenium is readily metabolized and involved in a range of metabolic functions that include assimilation, methylation, detoxification, and anaerobic respiration. In that regard, anaerobic digesters treating organic waste and operating at high ammonia concentrations are operated stably with selenium supplement at $0.16 \mathrm{mg}$ selenium per $\mathrm{kg}$ of fresh organic matter feed [81-83].

In a related fact, after ingestion, selenium is absorbed by the human body mainly in the duodenum and caecum via active transport through a sodium pump. The mechanisms of intestinal absorption of selenium differ depending on the chemical form of the element. When it is in excess, it is excreted through the urine and feces. Its homeostasis is based on reserves of selenomethionine in the kidney and liver [76, 84-87]. Humans can get selenium from food items such as Brazil nuts, kidney, liver wheat (grown in selenium rich countries) and drinking water [88].

Regarding the biochemistry of selenium, whether it is essential for higher plants metabolism or not, is debatable though most argue it is not $[19,21]$. However, there is a possible incorporation of trace amount of the element into specific selenoproteins for which the "S-assimilation" pathway is proposed where selenium is metabolized by the enzymes of sulphate assimilation both in accumulators and non-accumulators. Further, the accumulation selenium varies within the plant where shoot and root are most accumulators [21]. Whether selenium benefits higher plants metabolism or not, a more concern as well as an opportunity is the issue of phytotoxicity and its implication to human. On one hand, hyper-accumulators do benefit through phytoremediation of selenium contaminated sites, on the other hand consumption of selenium pounded plants could result in human selenium toxicity while the less-accumulators would open the potential to human nutrient supplement [89]. 


\section{Selenium quantification in an environmental sample}

Several instrumental and analytical methods including microwave digestion and fluorescence detection are applied to determine selenium in environmental samples in the recent past $[61,88]$. Due to the narrow margin between the essential selenium and selenium toxicity, the detection sensor material, electrode surface modifiers and chelators that overcome various challenges and achieve better detection limit, range, reproducibility, stability, selectivity, sensitivity, and so forth got advanced as reported by Devi et al., and Paikaray. Further the type of sample matters on the choice of a particular or group of detection methods as well as whether quantification or speciation is sought. In that regard a recipe depicting various environmental samples versus quantification and speciation is given in Fig. 9 [1, 17, 61].

Generally, selenium detection techniques can apply either the destructive method that includes the inductively coupled plasma mass spectroscopy (ICP-MS), a hydride generation atomic fluorescence spectrometer (HG-AFS) or the hydride generation atomic absorption spectroscopy (HGAAS). The non-destructive methods such as the Instrumental Neutron Activation Analysis (INAA) are also gaining attention. If the desire is routine detection but a simultaneous detection of multielement per sample, then the use of ICP-MS is advised $[1,90]$. The INNA can, especially be applied to low detection $\left(10^{-8}-10^{-9} \mathrm{~g}\right)$ multielemental analysis in an air sample though better detection limits and selenium speciation in an environmental sample can be achieved using HGAAS $(0.1 \mu \mathrm{g})[1,91-94]$. In spite of the advances in detection of selenium in an air sample, obtaining composite air sample is complicated and field-deployable air sampling method has been challenging until a simultaneous preconcentrating analysis method is forwarded [95].

However, conventionally, gas chromatography (GC), high-performance liquid chromatography (HPLC), ICPMS, neutron activation analysis (NAA), atomic fluorescence spectrophotometry (AFS), AAS, electrothermal AAS, and graphite furnace AAS (GF-AAS) are widely applied. Moreover, for improved detection and speciation, hyphenated separation methods including lon chromatography (IC) and capillary electrophoresis (CE) are used in conjugation with various atomic spectrophotometry detection systems such as Electrothermal AAS and plasmic optical emission spectroscopy (POES) [5].

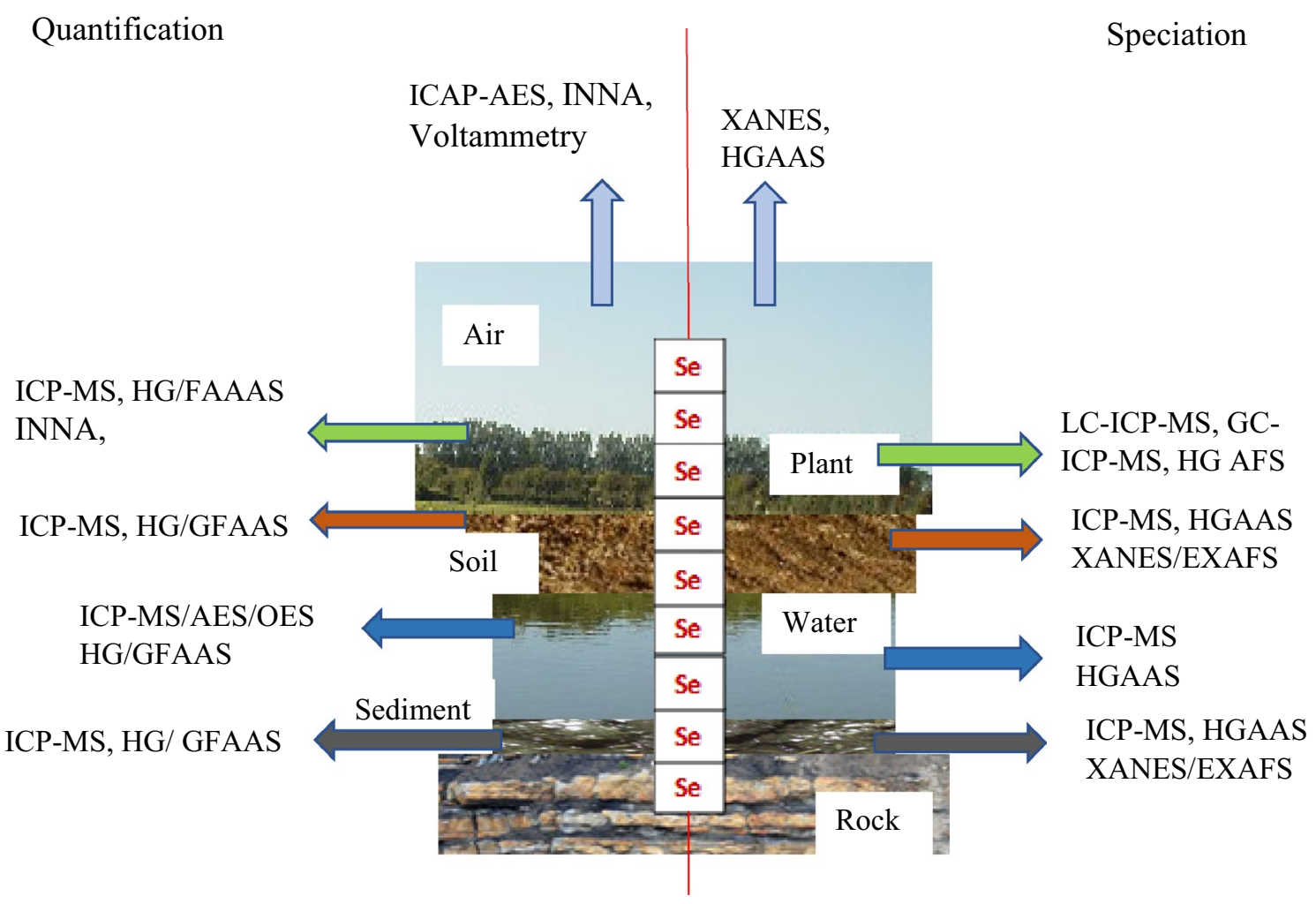

Fig. 9 Selenium detection from an environmental sample for speciation and quantification. (Redrawn from [1] with permission from John Wiley and Sons. $\odot 2016$ WILEY-VCH Verlag GmbH \& Co. KGaA, Weinheim) 
For trace analysis of toxic elements, it is not only necessary to determine the total content of the element in question at lower and lower levels, but it is also necessary to elucidate the binding state in order to evaluate the ecotoxicity and to follow the pathways of these elements in the environment and their metabolism in biological systems. Speciation of toxic as well as the essential elements are therefore important through the detection of forms of selenium.

Therefore, as applied to unravel selenium sorption mechanisms that rely on an interaction of some source of $\mathrm{X}$-ray excitation and a sample, diverse advanced detection techniques are emerging which include energy-dispersive $X$-ray spectroscopy (EDXRS), Fourier-transform infrared spectroscopy (FT-IR), powered X-ray diffraction (PXRD), extended X-Ray absorption fine structure (EXAFS) and X-ray absorption spectroscopy (XAS) [96].

\section{Management of the excess selenium in water and soil media}

Diverse technologies are being applied to remove selenium from water, soil, sediment and sludge [97]. These technologies are applied at laboratory, pilot and full-scale levels $[46,98]$. By their working principle, these technologies encompass physico-chemical and biological methods. For instance, the full-scale application systems in selenium removal include fixed bed biological filters, constructed wetlands and reverse osmosis. Table 2 below gives a glimpse of the classes of selenium remediation technologies with the corresponding examples that are partly detailed in Table 3 including the advantage and disadvantage as well as process description.

\subsection{Conventional selenium management techniques}

Numerous physicochemical methods have been used to reduce the level of selenium from drinking water as well as to meet discharge limits by the process industries. For instance, the order of $1-5 \mu \mathrm{g} / \mathrm{l}$ is sought in the United States and other selenium rich nations. Conventionally the following techniques are applied to meet standards in drinking water supply.

1. Biological reduction following pretreatment.

2. lon exchange,

3. Activated alumina (AA),

4. Reverse osmosis (RO), and

5. Distillation.

Ion (anion) exchange can reduce selenium by up to $95 \%$, in which the selenate ion is strongly preferred. Although $\mathrm{Se}(\mathrm{IV})$ is more difficult to oxidize compared to As (III) which is oxidized to As (V), this can readily be accomplished with the application of excess chlorine. The optimum amount of oxidation is obtained between $\mathrm{pH} 6.5$ and 8.0 where Se (IV) can be converted to Se (VI) within five minutes at a free chlorine concentration of $2 \mathrm{mg} / \mathrm{l}$. At pH 9.0 , only $15 \%$ of the Se (IV) has been found to be converted with $2 \mathrm{mg} / \mathrm{l}$ of free chlorine. Other techniques used for selenium removal include distillation ( $>98 \%$ reduction), reverse osmosis (RO) ( $>90 \%$ reduction) and activated alumina $(85-95 \%$ reduction) $[87,99,100]$ (Table 3$)$.

Removal of the excess selenium from drinking water entered to a conventional scale especially in selenium rich countries through the application of the biological reduction technique. In such regard, fixed-film fluidized bed reactor (FF-FBR), commercially called "ABMet", has got wider application. Recently, developments on the application of this biotechnology to mineralize selenium as extracellular and intracellular precipitation of selenium biominerals have been reported using selenate respiring bacterium [101].

Comparatively, despite its pretreatment and management cost, pressure driven separations including $\mathrm{RO}$ are also applied to full scale. Some removal techniques are at pilot scale and few are still on a rigorous study especially the electrocoagulation method as explained in Table 3.

\subsection{Recent developments on selenium management research}

Since selenium contamination in groundwater and surface water in numerous river basins worldwide has become a
Table 2 Brief summary of classes of selenium removal technologies with examples

\begin{tabular}{lll}
\hline No & Classes of technology & Examples \\
\hline 1 & Chemical & lon exchange with adsorption, catalyzed reduction \\
2 & Adsorption & Activated carbon, peanut shell, activated alumina, ferrihydrite \\
3 & Phytoremediation & Wet land, algal volatilization \\
4 & Coagulation precipitation & Electrocoagulation \\
5 & Bioremediation (excluding & Enzymatic selenium reduction, enhanced in situ microbial \\
& phytoremediation) & reduction, algal-bacterial removal \\
6 & Pressure driven separations & Nano-filtration and reverse osmosis \\
\hline
\end{tabular}




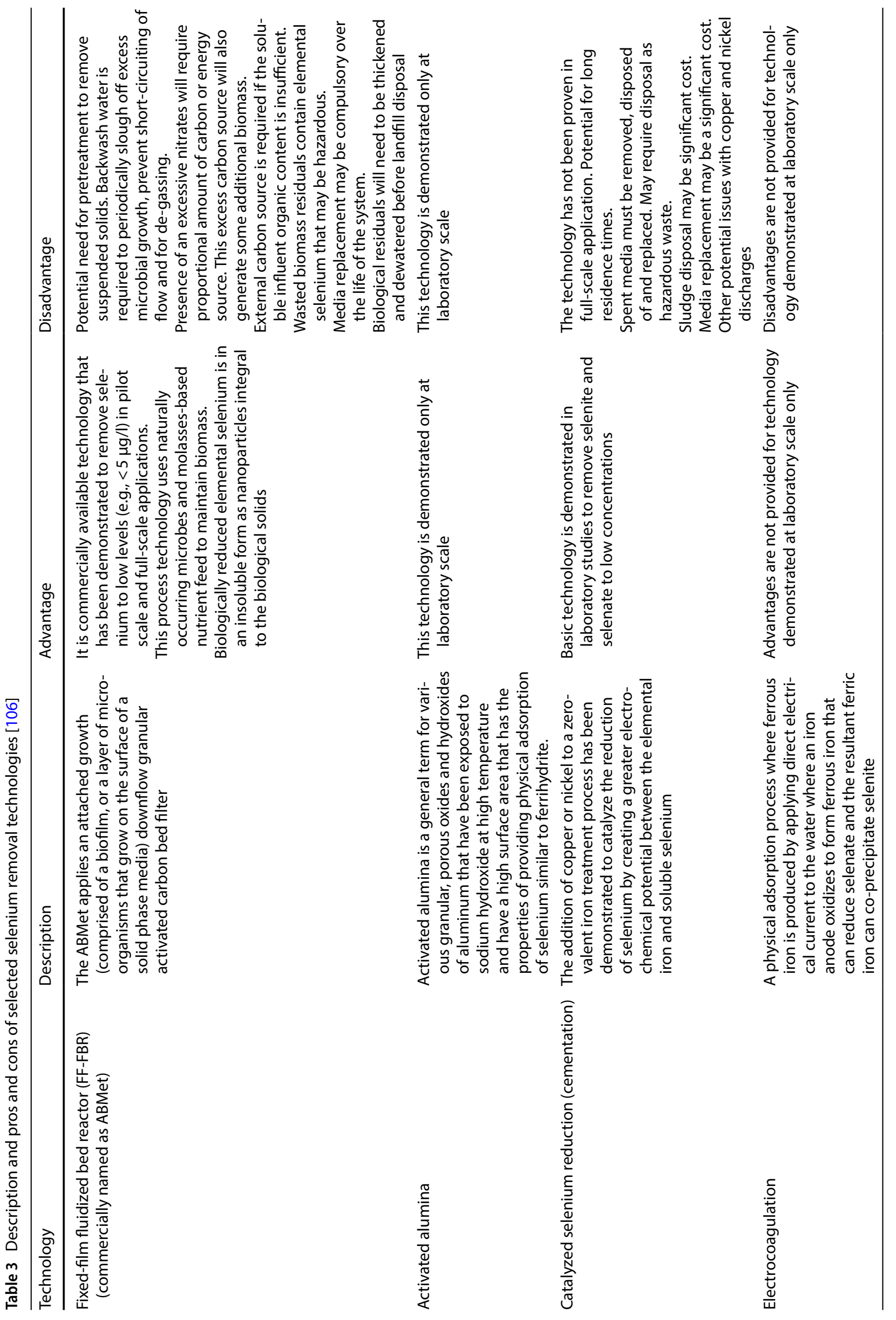




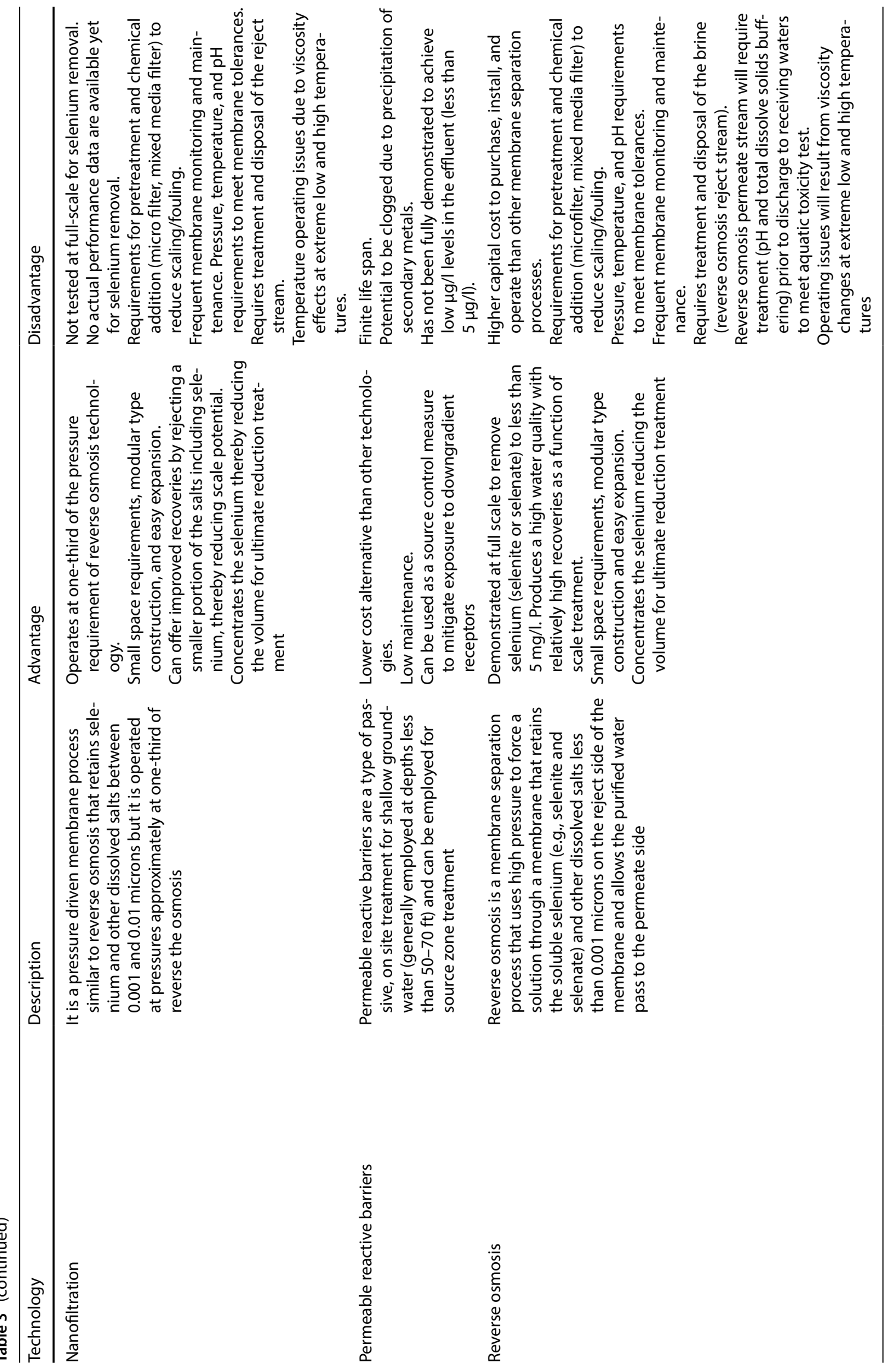


critical issue in recent decades [46], researches in selenium environmental management are gaining wider attention. Among the various endeavors attempted, phytoremediation, sorption and use of characteristically identified microbes are worth to mention.

Basically, phytoremediation is a biological approach to pollution control or management activities that apply selenium selective plants species as portrayed on Fig. 10 $[102,103]$. The mechanism by which plants take up, transport and transform selenium is nearly similar as illustrated in Fig. 11. Accordingly, a selenium concentration of $1 \mathrm{~g} /$ $\mathrm{kg} \mathrm{DW}$ of plants is reported from phytoremediation of contaminated site using hyper accumulator plant species (Fig. 10). In that regard, the hyper accumulators including giant reed to clean selenium-contaminated sites are also conveyed in recent publications $[7,55,76]$. In a related study water hyacinth (Eichhornia crassipes) were tested for their pollutant metal sequestering potential [104] that can also potentially be considered for selenium removal [105]. However, the later management of the biomass will be a challenge for future research.

Organo-selenium, selenite and selenate in the soil are taken up through the plants' physiological system involving the root transport system and are either incorporated in selenium-protein, accumulated in their leaf or dissipated into the air after methylation (Fig. 11) [95].

Sorption of selenium is another attractive removal technology which is proved efficient in removing selenium from an environmental media and yet it is an older technique. For instance, sorption of selenium using minerals

Fig. 10 Classification of plants depending upon selenium accumulation as hyperaccumulators, secondary accumulators and non-accumulators. (Source: [7])

like hydrated lime and calcium-based particles proved to be efficient based on an XRD evaluation [107, 108]. Adsorption of selenium is a phenomenon that co-occurs during a metabolic process [10].

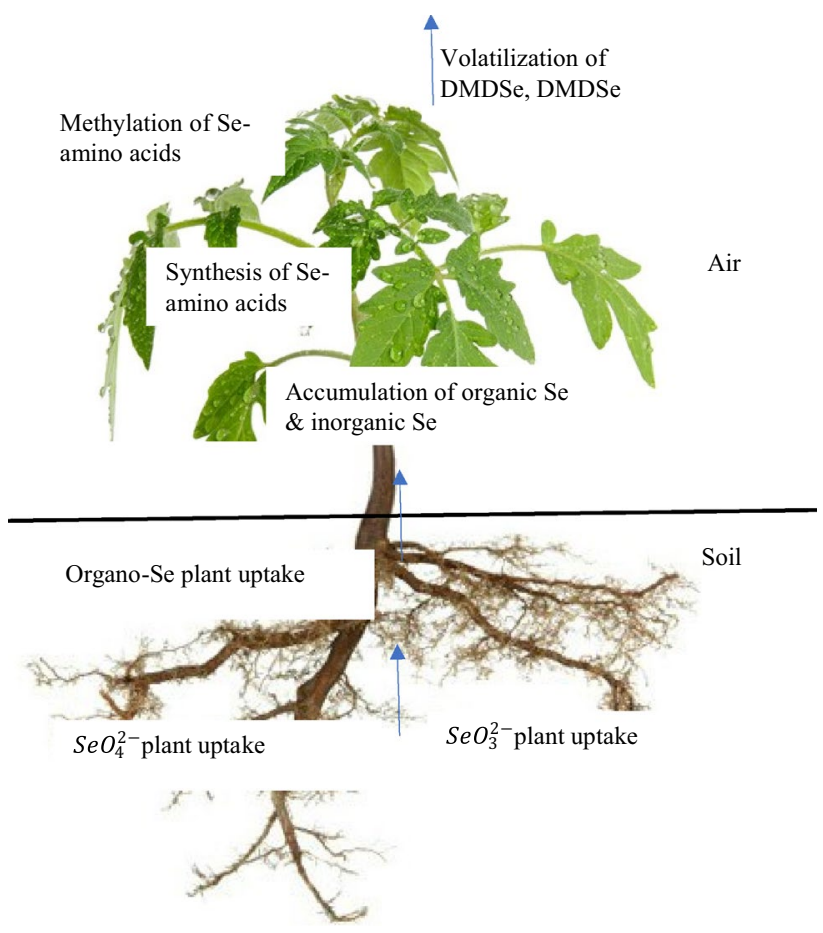

Fig. 11 Selenium uptake by plants. (Adapted from [50])

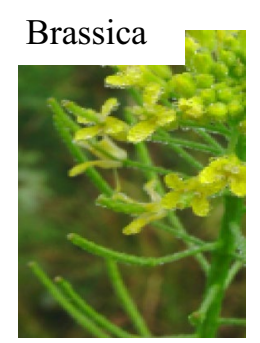

Secondary-accumulators $100-1000 \mathrm{mg}-\mathrm{Se} / \mathrm{kg}$ DW

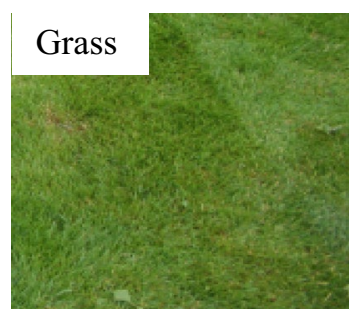

Non-accumulators $<100 \mathrm{mg}-\mathrm{Se} / \mathrm{kg}$ DW
Hyper-accumulators $>1000 \mathrm{mg}-\mathrm{Se} / \mathrm{kg}$ DW

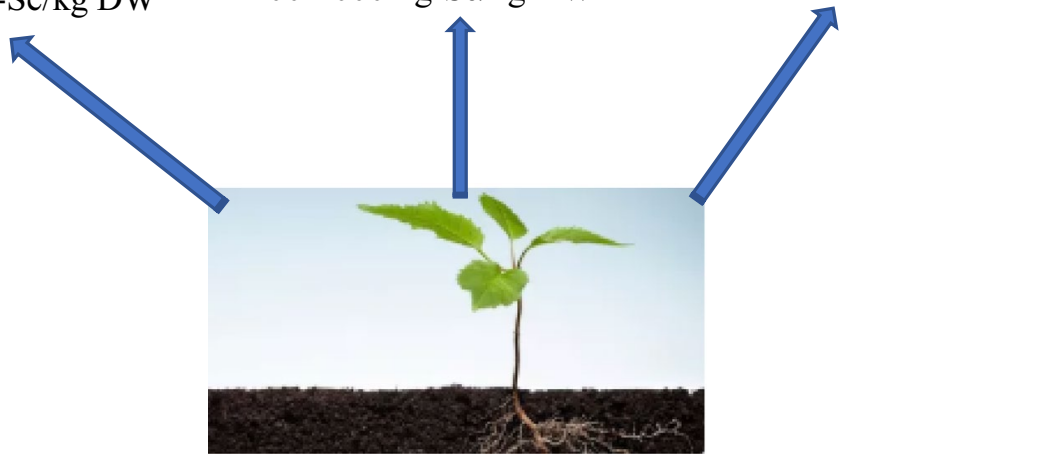


In a related current study, sorption of selenium is tested using rare earth hydroxide since the contents of selenium in industrial wastewater, agricultural runoff, and drinking water have to be constrained to a value of $50 \mu \mathrm{g} / \mathrm{l}$, as the maximum concentration limit [109]. This recent experimental research reported that selenium can be sequestered efficiently from its aqueous solution using a structurally well-defined cationic layered rare earth hydroxide, $\mathrm{Y}_{2}(\mathrm{OH})_{5} \mathrm{Cl} \cdot 1.5 \mathrm{H}_{2} \mathrm{O}$ (Fig. 12) with maximum sorption capacities of selenite and selenate reported are 207 and $124 \mathrm{mg} / \mathrm{g}$, respectively, both representing the new records among the inorganic sorbents. In the low concentration region, $\mathrm{Y}_{2}(\mathrm{OH})_{5} \mathrm{Cl} \cdot 1.5 \mathrm{H}_{2} \mathrm{O}$ is able to almost completely remove selenium from aqueous solution even in the presence of competitive anions such as $\mathrm{NO}_{3}{ }^{-}, \mathrm{Cl}^{-}, \mathrm{CO}_{3}{ }^{2-}, \mathrm{SO}_{4}$ ${ }^{2-}$, and $\mathrm{HPO}_{4}{ }^{2-}$. The resulting concentration $10 \mathrm{~A} \mu \mathrm{g} / \mathrm{l}$ is achieved. The sorption kinetics is well fitted in the Langmuir model in two different $\mathrm{pH}$ levels, 7 and 8.5; however, the selenium sorption decreased at the higher pH (Fig. 13).

Observing the surface phenomena closely, the sorption mechanism was unraveled by the combination of advanced techniques like EDS, FT-IR, PXRD, and EXAFS. Selenate ions were exchanged with chloride ions in the interlayer space, forming outer-sphere complexes. In comparison, besides anion exchange mechanism, the selenite ions were directly bind to the $\mathrm{Y}^{3+}$ center in the positively charged layer of $\left[\mathrm{Y}_{2}(\mathrm{OH})_{5}\left(\mathrm{H}_{2} \mathrm{O}\right)\right]^{+}$through strong bidentate binuclear inner-sphere complexation, consistent with the observation of the higher uptake of selenite over selenate [109].

Waste sludge of domestic or industrial origin is becoming another selenium mine sites. Like other recovery operations, selenium is being obtained through sludge mining: Pseudomonas stutzeri NT- I to reduce the soluble selenium compounds to elemental selenium, Se(0) [110] in another study. Michihiko Ike and colleagues at Osaka University, have developed a process to mineralize selenium through microbial recovery though the technique is obscured. This element is also present in industrial wastewater streams, for instance, from copper production [111].
However, much of the recovery efforts are on a laboratory scale which is mainly due to gaps in the method applied and the associated cost implications.

\section{Conclusion}

Selenium occurrence, geochemistry, nutrient and toxicity effect remained concerns worldwide. Advances in analytical methods and instrumentation, selenium detection and speciation helped in understanding selenium's environmental process in more detail. Selenium's natural distribution is globally uneven; for some it is scarce but for others, it needs removal from an environmental medium. In addition, the selenium intake by animals involves both food and water and hence the toxicity risk has to consider both factors. Furthermore, the selenium mobility associated risk is largely the selenium species specific, environmental $\mathrm{pH}$ and redox potential dependent.

Regarding selenium management, reduction is the most feasible chemical technology to remove selenium. The biological methods are most established, especially in using phytoremediation and microbial reduction, the latter being largely applied in drinking water supply systems. Similarly, the application of surface phenomena to remove selenium is advancing with time. Thus, selenium sorption and isotherm are elucidated in recent works.

Yet, selenium remains to be a concern in geogenic and anthropogenic contamination as well as in nutrient supplement effect. The recovery of selenium from anthropogenic sources of release is also equally important. However, there is a huge geographical imbalance in selenium studies and publications, the least studies being in the African continent.

Research and development towards implementation and provision of an adequate institutional framework and marketing chains to increase the use of recovered selenium materials require feasibility studies. Furthermore, technologies for efficient recovery and reuse of recovered selenium with consideration of speciation, purity and
Fig. 12 Selenium adsorption in rare earth hydroxide. (Adapted with permission from [109]. (c) 2017 American Chemical Society)

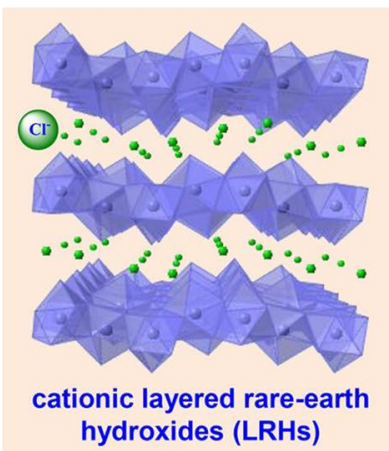

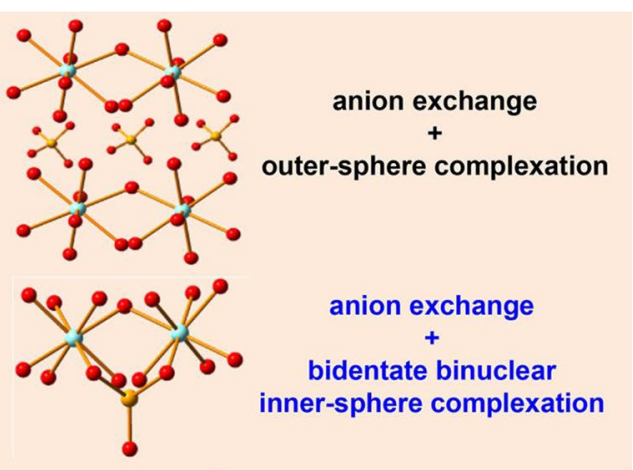



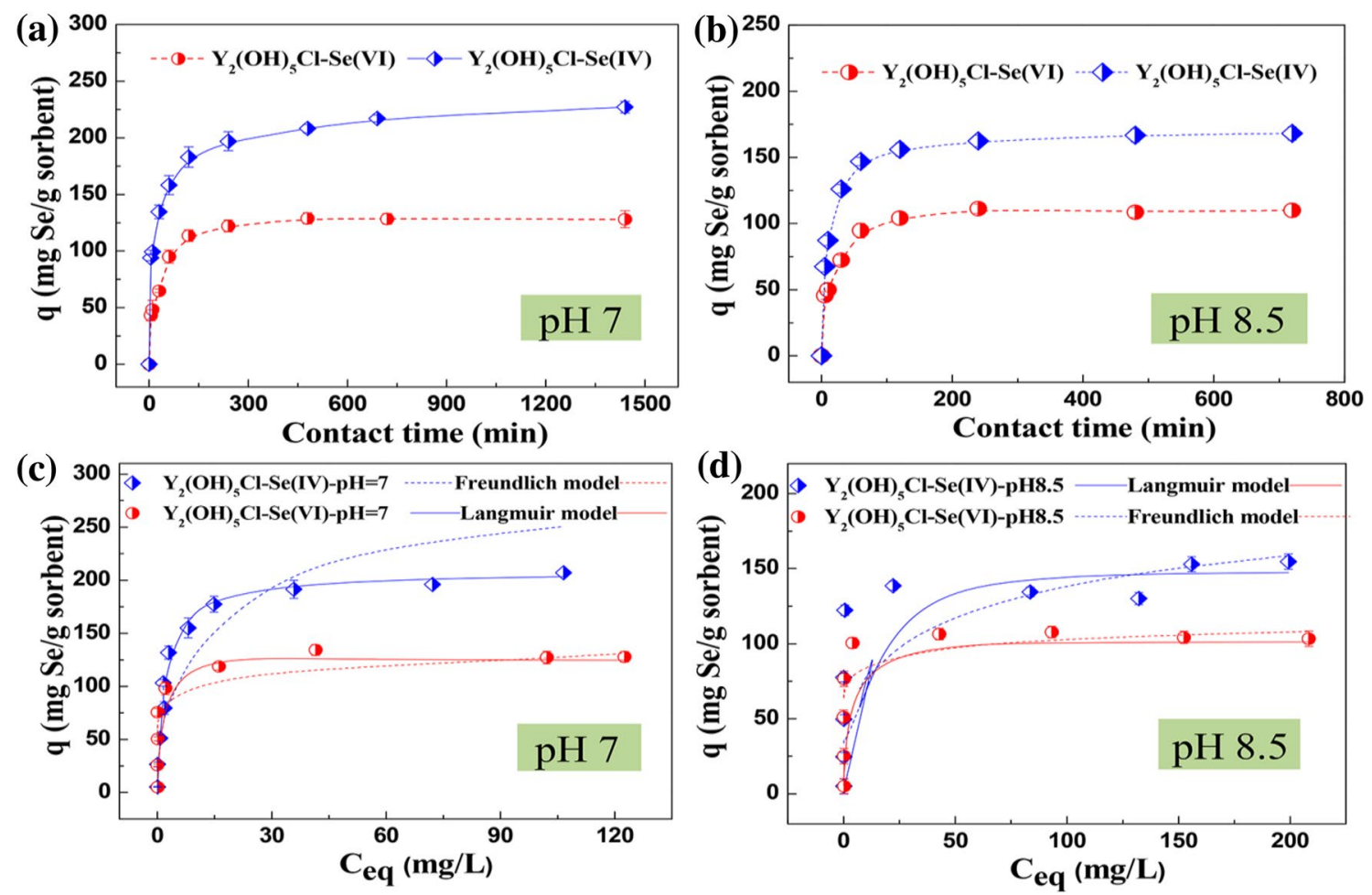

Fig. 13 Sorption kinetics of Se (IV) and Se (VI) on $\mathrm{Y}_{2}(\mathrm{OH})_{5} \mathrm{Cl} \cdot 1.5 \mathrm{H}_{2} \mathrm{O}$ at $\mathbf{a} \mathrm{pH} 7$ and $\mathbf{b}$ 8.5. Sorption isotherms of Se (IV) and Se (VI) on $\mathrm{Y}_{2}(\mathrm{OH})_{5} \mathrm{Cl} \cdot 1.5 \mathrm{H}_{2} \mathrm{O}$ at $\mathbf{c ~ p H ~} 7$ and $\mathbf{d}$ 8.5. (Phase ratio $=2 \mathrm{~g} / \mathrm{l}$, contact

time $=12 \mathrm{~h}$, background $=0.01 \mathrm{M} \mathrm{NaCl}$. (Adapted with permission from [109]. ๑ 2017 American Chemical Society)

value are highly sought. In such regard, integrating selenium sequestered plants as source of selenium requires those advanced separation techniques. However, the extraction of the plant sequestered selenium is a future challenge that needs to be addressed.

Acknowledgements We are thankful to the African Center of Excellence for Water Management, Addis Ababa University, Ethiopia for the kind support it has made.

\section{Compliance with ethical standards}

Conflict of interest The authors declare that they have no conflict of interest.

\section{References}

1. Paikaray S (2015) Origin, mobilization and distribution of selenium in a soil/water/air system: a global perspective with special reference to the indian scenario. CLEAN Soil Air Water 44(5):474-487

2. Morrison SJ, Goodknight CS, Tigar AD, Bush RP, Gil A (2012) Naturally occurring contamination in the Mancos Shale. Environ Sci Technol 46(3):1379-1387

3. Devitt DA, Wright LE, Shanahan SA, Hausrath E (2014) Fate of selenium in a small urban watershed. Environ Monit Assess 186(5):3181-3197

\section{SN Applied Sciences}

4. Pettine $M$, McDonald TJ, Sohn M, Anquandah GAK, Zboril R, Sharma VK (2015) A critical review of selenium analysis in natural water samples. Trends Environ Anal Chem 5:1-7

5. Bailey RT (2017) Review: Selenium contamination, fate, and reactive transport in groundwater in relation to human health. Hydrogeol J 25(4):1191-1217

6. Grützmacher G, Kumar PS, Rustler M, Hannappel S, Sauer U (2013) Geogenic groundwater contamination-definition, occurrence and relevance for drinking water production. $\mathrm{Zbl}$ Geol Paläont Teil I 1:69-75

7. Gupta M, Gupta S (2017) An overview of selenium uptake, metabolism, and toxicity in plants. Front Plant Sci 7:1-14

8. Fernández-Lodeiro J, Pinatto-Botelho MF, Soares-Paulino AA, Gonçalves AC, Sousa BA, Princival C, Dos Santos AA (2014) Synthesis and biological properties of selenium- and telluriumcontaining dyes. Dyes Pigment 110:28-48

9. Gaskill C (2008) Veterinary toxicology-basic and clinical principles. Can Vet J 49(6):591

10. Lopes G, Ávila FW, Guilherme LRG (2017) Selenium behavior in the soil environment and its implication for human health. Ciência e Agrotec 41:605-615

11. Broadley MR, White PJ, Bryson RJ, Meacham MC, Bowen HC, Johnson SE, Hawkesford MJ, McGrath SP, Zhao F-J, Breward N, Harriman M, Tucker M (2007) Biofortification of UK food crops with selenium. Proc Nutr Soc 65(2):169-181

12. Levander OA, Burk RF (2006) Update of human dietary standards for selenium. In: Hatfield DL, Berry MJ, Gladyshev VN (eds) Selenium: its molecular biology and role in human health. Springer, Boston, pp 399-410 
13. Benemariya $H$, Robberecht $H$, Deelstra $H$ (1993) Daily dietary intake of copper, zinc and selenium by different population groups in Burundi, Africa. Sci Total Environ 136(1):49-76

14. Kipp AP, Strohm D, Brigelius-Flohé R, Schomburg L, Bechthold A, Leschik-Bonnet $\mathrm{E}$, Heseker $\mathrm{H}$ (2015) Revised reference values for selenium intake. J Trace Elem Med Biol 32:195-199

15. Gordon JEH (1875) Anomalous Behaviour of Selenium. Nature $12: 187$

16. Da Silva JF, Williams RJP (2001) The biological chemistry of the elements: the inorganic chemistry of life. Oxford University Press, New York

17. Devi P, Jain R, Thakur A, Kumar M, Labhsetwar NK, Nayak M, Kumar P (2017) A systematic review and meta-analysis of voltammetric and optical techniques for inorganic selenium determination in water. TrAC Trends Anal Chem 95:69-85

18. Gasiewicz TA, Smith JC (1978) Properties of the cadmium and selenium complex formed in rat plasma in vivo and in vitro. Chem Biol Interact 23(2):171-183

19. White PJ (2016) Selenium accumulation by plants. Ann Bot 117(2):217-235

20. Gupta M, Gupta S (2016) An overview of selenium uptake, metabolism, and toxicity in plants. Front Plant Sci 7:2074

21. Terry N, Zayed A, De Souza M, Tarun A (2000) Selenium in higher plants. Annu Rev Plant Biol 51(1):401-432

22. Brown TA, Shrift A (1982) Selenium: toxicity and tolerance in higher plants. Biol Rev 57(1):59-84

23. Garousi F (2017) Toxicity of selenium, application of selenium in fertilizers, selenium treatment of seeds, and selenium in edible parts of plants. Acta Univ Sapientiae Aliment 10(1):61-74

24. Sun G-X, Liu X, Williams PN, Zhu Y-G (2010) Distribution and translocation of selenium from soil to grain and its speciation in paddy rice (Oryza sativa L.). Environ Sci Technol 44(17):6706-6711

25. Kaur N, Sharma S, Kaur S, Nayyar H (2014) Selenium in agriculture: a nutrient or contaminant for crops? Arch Agron Soil Sci 60(12):1593-1624

26. Sharadamma K, Purushotham B, Radhakrishna P, Abhilekha $P$, Vagdevi $H$ (2011) Role of selenium in pets health and nutrition: a review. Asian J Animal Sci 5(1):64-70

27. Council NR (1983) Selenium in nutrition: revised edition. National Academies Press, Washington, DC

28. Desta B, Maldonado G, Reid H, Puschner B, Maxwell J, Agasan A, Humphreys L, Holt T (2011) Acute selenium toxicosis in polo ponies. J Vet Diagn Invest 23(3):623-628

29. Olson OE (1986) Selenium toxicity in animals with emphasis on man. J Am Coll Toxicol 5(1):45-70

30. Kurek E, Ruszczyńska A, Wojciechowski M, Czauderna M, Bulska $E$ (2009) Study on speciation of selenium in animal tissues using high performance liquid chromatography with on-line detection by inductively coupled plasma mass spectrometry. Chemia Analityczna 54:43-57

31. Benemariya H, Robberecht $H$, Deelstra H (1993) Zinc, copper, and selenium in milk and organs of cow and goat from Burundi, Africa. Sci Total Environ 128(1):83-98

32. Fordyce FM (2013) Selenium deficiency and toxicity in the environment. In: Selinus O (ed) Essentials of medical geology: revised edition. Springer, Dordrecht, pp 375-416

33. Lemly AD (2004) Aquatic selenium pollution is a global environmental safety issue. Ecotoxicol Environ Saf 59(1):44-56

34. Lemly AD (1997) Environmental implications of excessive selenium: a review. Biomed Environ Sci 21:415-435

35. Etim EU (2017) Occurrence and distribution of arsenic, antimony and selenium in shallow groundwater systems of Ibadan Metropolis, Southwestern Nigerian. J Health Pollut 7(13):32-41

36. Bassil J, Naveau A, Bueno M, Razack M, Kazpard V (2018) Leaching behavior of selenium from the karst infillings of the hydrogeological experimental site of Poitiers. Chem Geol 483:141-150

37. Tan LC, Nancharaiah YV, van Hullebusch ED, Lens PNL (2016) Selenium: environmental significance, pollution, and biological treatment technologies. Biotechnol Adv 34(5):886-907

38. Barceloux DG, Barceloux D (1999) Selenium. J Toxicol Clin Toxicol 37(2):145-172

39. Vinceti M, Wei ET, Malagoli C, Bergomi M, Vivoli G (2001) Adverse health effects of selenium in humans. Rev Environ Health 16(4):233-251

40. Vinceti M, Mandrioli J, Borella P, Michalke B, Tsatsakis A, Finkelstein $Y$ (2014) Selenium neurotoxicity in humans: bridging laboratory and epidemiologic studies. Toxicol Lett 230(2):295-303

41. MacFarquhar JK, Broussard DL, Melstrom $P$, Hutchinson R, Wolkin A, Martin C, Burk RF, Dunn JR, Green AL, Hammond R, Schaffner W, Jones TF (2010) Acute selenium toxicity associated with a dietary supplement. Arch Intern Med 170(3):256-261

42. Aldosary BM, Sutter ME, Schwartz M, Morgan BW (2012) Case series of selenium toxicity from a nutritional supplement. Clin Toxicol 50(1):57-64

43. Fan AM, Kizer KW (1990) Selenium. Nutritional, toxicologic, and clinical aspects. West J Med 153(2):160-167

44. Kubota S, Tsuchiya Y (2009) Water quality and standards. Eolss Publishers, Oxford

45. Fan AM, Vinceti M (2015) Selenium and its compounds, in Hamilton \& Hardy's industrial toxicology. Wiley, Hoboken

46. Bailey RT, Romero EC, Gates TK (2015) Assessing best management practices for remediation of selenium loading in groundwater to streams in an irrigated region. J Hydrol 521:341-359

47. Santos S, Ungureanu G, Boaventura R, Botelho C (2015) Selenium contaminated waters: an overview of analytical methods, treatment options and recent advances in sorption methods. Sci Total Environ 521-522:246-260

48. Bailey RT, Gates TK, Halvorson AD (2013) Simulating variablysaturated reactive transport of selenium and nitrogen in agricultural groundwater systems. J Contam Hydrol 149:27-45

49. Martens DA, Suarez DL (1997) Selenium speciation of soil/ sediment determined with sequential extractions and hydride generation atomic absorption spectrophotometry. Environ Sci Technol 31(1):133-139

50. Winkel LHE, Vriens B, Jones GD, Schneider LS, Pilon-Smits E, Bañuelos GS (2015) Selenium cycling across soil-plant-atmosphere interfaces: a critical review. Nutrients 7(6):4199-4239

51. Xing K, Zhou S, Wu X, Zhu Y, Kong J, Shao T, Tao X (2015) Concentrations and characteristics of selenium in soil samples from Dashan Region, a selenium-enriched area in China. Soil Sci Plant Nutr 61(6):889-897

52. Mast MA, Mills TJ, Paschke SS, Keith G, Linard JI (2014) Mobilization of selenium from the Mancos Shale and associated soils in the lower Uncompahgre River Basin, Colorado. Appl Geochem 48:16-27

53. Fellowes JW, Pattrick RAD, Boothman C, Al Lawati WMM, van Dongen BE, Charnock JM, Lloyd JR, Pearce Cl (2013) Microbial selenium transformations in seleniferous soils. Eur J Soil Sci 64(5):629-638

54. Bassil J, Naveau A, Bueno M, Di Tullo P, Grasset L, Kazpard V, Razack M (2016) Determination of the distribution and speciation of selenium in an argillaceous sample using chemical extractions and post-extractions analyses: application to the hydrogeological experimental site of Poitiers. Environ Sci Pollut Res 23(10):9598-9613

55. El-Ramady H, Abdalla N, Alshaal T, El-Henawy A, Faizy S, Belal E, Shehata S, Amer M, Fa'ri MS, Sztrik A, Schnug E, Pilon-Smits Samia EAH, El-Marsafawy M, Domokos-szabolcsy E (2015) Giant reed for selenium phytoremediation under changing climate. Environ Chem Lett 13:359-380 
56. Jakubowski N, Thomas C, Stuewer D, Dettlaff I, Schram J (1996) Speciation of inorganic selenium by inductively coupled plasma mass spectrometry with hydraulic high pressure nebulization. J Anal At Spectrom 11(11):1023-1029

57. Ponomarenko $O$, La Porte PF, Singh SP, Langan G, Fleming DEB, Spallholz JE, Alauddin M, Ahsan H, Ahmed S, Gailer J, George GN, Pickering IJ (2017) Selenium-mediated arsenic excretion in mammals: a synchrotron-based study of whole-body distribution and tissue-specific chemistry. Met Integr Biometal Sci 9(11):1585-1595

58. Willett WC, MacMahon B (1984) Diet and cancer-an overview. N Engl J Med 310(11):697-703

59. Hurst R, Siyame EWP, Young SD, Chilimba ADC, Joy EJM, Black CR, Ander EL, Watts MJ, Chilima B, Gondwe J, Kang'ombe D, Stein AJ, Fairweather-Tait SJ, Gibson RS, Kalimbira AA, Broadley MR (2013) Soil-type influences human selenium status and underlies widespread selenium deficiency risks in Malawi. Sci Rep 3:1425

60. Sami K, Druzynski A (2013) South African Water Research Council [Online]. http://www.wrc.org.za/Pages/Displaylte m.aspx?ltemID=7713\&FromURL=\%2FPages\%2FAllKH.aspx\%3F. Accessed Sept 2018

61. Pyrzyńska K (2002) Determination of selenium species in environmental samples. Microchim Acta 140(1):55-62

62. Murray MP, Sharmin R (2015) Groundwater arsenic and education attainment in Bangladesh. J Health Popul Nutr 33:20

63. IS 10500 B (2012) Indian standard drinking water-specification (second revision). Bureau of Indian Standards (BIS), New Delhi

64. Kebede S (2012) Groundwater in Ethiopia: features, numbers and opportunities. Springer, Berlin, pp 83-92

65. Dagnaw LA, Chandravanshi B, Zewge F, Ababa A (2018) Fluoride content of leafy vegetables, irrigation water, and farmland soil in the rift valley and in non-rift valley areas of Ethiopia. Fluoride 50:409-429

66. Wendimu G, Zewge F, Mulugeta E (2017) Aluminium-ironamended activated bamboo charcoal (AIAABC) for fluoride removal from aqueous solutions. J Water Process Eng 16:123-131

67. Zewge $F$ (2017) Combined aluminium sulfate/hydroxide process for fluoride removal from drinking water. Bull Chem Soc Ethiop 30:391

68. Floor GH, Iglesías M, Román-Ross G, Corvini PFX, Lenz M (2011) Selenium speciation in acidic environmental samples: application to acid rain-soil interaction at Mount Etna volcano. Chemosphere 84(11):1664-1670

69. McNeal JM, Balistrieri LS (1989) Geochemistry and occurrence of selenium: an overview. In: Selenium in agriculture and the environment (seleniuminagric), pp 1-13

70. Violante A, Cozzolino V, Perelomov L, Caporale A, Pigna M (2010) Mobility and bioavailability of heavy metals and metalloids in soil environments. J Soil Sci Plant Nutr 10(3):268-292

71. Mills TJ, Mast MA, Thomas J, Keith G (2016) Controls on selenium distribution and mobilization in an irrigated shallow groundwater system underlain by Mancos Shale, Uncompahgre River Basin, Colorado, USA. Sci Total Environ 566-567:1621-1631

72. Tsui EY, Hartstein KH, Gamelin DR (2016) Selenium Redox reactivity on colloidal CdSe quantum dot surfaces. J Am Chem Soc 138(35):11105-11108

73. Carroll L, Pattison DI, Fu S, Schiesser CH, Davies MJ, Hawkins CL (2015) Reactivity of selenium-containing compounds with myeloperoxidase-derived chlorinating oxidants: second-order rate constants and implications for biological damage. Free Radic Biol Med 84:279-288
74. Wilkins Lewis $C$, Günther Benjamin AR, Walther M, Lawson James R, Wirth T, Melen Rebecca L (2016) Contrasting frustrated Lewis pair reactivity with selenium- and boron-based Lewis acids. Angewandte Chemie Int Ed 55(37):11292-11295

75. Freudendahl DM, Wirth T (2011) New selenium electrophiles and their reactivity. In: Woollins JD, Laitinen RS (eds) Selenium and tellurium chemistry. Springer, Berlin, pp 41-55

76. Stadtman TC (1974) Selenium biochemistry. Science 183(4128):915

77. Stadtman TC (1990) Selenium biochemistry. Annu Rev Biochem 59(1):111-127

78. Reddy CC, Massaro EJ (1983) Biochemistry of selenium: a brief overview. Fundam Appl Toxicol 3(5):431-436

79. Stolz JF, Basu P, Santini JM, Oremland RS (2006) Arsenic and selenium in microbial metabolism. Annu Rev Microbiol 60(1):107-130

80. Nancharaiah YV, Lens PNL (2015) Selenium biomineralization for biotechnological applications. Trends Biotechnol 33(6):323-330

81. Nancharaiah YV, Lens PNL (2015) Ecology and biotechnology of selenium-respiring bacteria. Microbiol Mol Biol Rev MMBR 79(1):61-80

82. Tang K, Baskaran V, Nemati M (2009) Bacteria of the sulphur cycle: an overview of microbiology, biokinetics and their role in petroleum and mining industries. Biochem Eng J 44(1):73-94

83. Bailey RT, Gates TK, Ahmadi M (2014) Simulating reactive transport of selenium coupled with nitrogen in a regional-scale irrigated groundwater system. J Hydrol 515:29-46

84. Jager T, Drexler H, Goen T (2016) Human metabolism and renal excretion of selenium compounds after oral ingestion of sodium selenite and selenized yeast dependent on the trimethylselenium ion (TMSe) status. Arch Toxicol 90(5):1069-1080

85. Bügel S, Larsen EH, Sloth JJ, Flytlie K, Overvad K, Steenberg LC, Moesgaard S (2008) Absorption, excretion, and retention of selenium from a high selenium yeast in men with a high intake of selenium. Food Nutr Res 52:1-8. https://doi.org/10.3402/fnr. v52i0.1642

86. Mehdi Y, Hornick J-L, Istasse L, Dufrasne I (2013) Selenium in the environment, metabolism and involvement in body functions. Molecules 18(3):3292-3311

87. Higashi RM, Cassel TA, Skorupa JP, Fan TW-M (2005) Remediation and bioremediation of selenium-contaminated waters. Water Encycl 2:355-360

88. Nahir TM, Sheffield M-C (2002) Analysis of selenium in Brazil Nuts by microwave digestion and fluorescence detection. J Chem Educ 79(11):1345

89. Natasha M, Shahid Niazi NK, Khalid S, Murtaza B, Bibi I, Rashid MI (2018) A critical review of selenium biogeochemical behavior in soil-plant system with an inference to human health. Environ Pollut 234:915-934

90. Ballihaut G, Pécheyran C, Mounicou S, Preud'homme H, Grimaud R, Lobinski R (2007) Multimode detection (LA-ICP-MS, MALDI-MS and nanoHPLC-ESI-MS2) in 1D and 2D gel electrophoresis for selenium-containing proteins. TrAC Trends Anal Chem 26(3):183-190

91. Uden PC (2002) Modern trends in the speciation of selenium by hyphenated techniques. Anal Bioanal Chem 373(6):422-431

92. Buchberger W (2001) Detection techniques in ion chromatography of inorganic ions. TrAC Trends Anal Chem 20(6-7):296-303

93. Vassileva E, Becker A, Broekaert J (2001) Determination of arsenic and selenium species in groundwater and soil extracts by ion chromatography coupled to inductively coupled plasma mass spectrometry. Anal Chim Acta 441(1):135-146 
94. Mazej D, Falnoga I, Veber M, Stibilj V (2006) Determination of selenium species in plant leaves by HPLC-UV-HG-AFS. Talanta 68(3):558-568

95. Vriens $B, A$ mmann AA, Hagendorfer $H$, Lenz M, Berg M, Winkel LH (2014) Quantification of methylated selenium, sulfur, and arsenic in the environment. PLoS ONE 9(7):e102906

96. Zhang C (2007) Fundamentals of environmental sampling and analysis. Wiley, New York, pp 172-241

97. van Hullebusch ED (2018) Remediation of selenium contaminated wastewater. In: Kallel $A$, Ksibi $M$, Ben Dhia $H$, Khélifi $N$ (eds) Recent advances in environmental science from the Euro-Mediterranean and surrounding regions. EMCEI 2017. Advances in science, technology \& innovation (IEREK Interdisciplinary Series for Sustainable Development). Springer, Cham

98. Zhang Y, Frankenberger WT (2003) Factors affecting removal of selenate in agricultural drainage water utilizing rice straw. Sci Total Environ 305(1):207-216

99. Remediation and Bioremediation of Selenium-Contaminated Waters, in Water Encyclopedia

100. Mahmoud MR, Soliman MA, Ali AH, Othman SH (2016) Kinetic studies on radio-selenium uptake by ion exchange resin. Sep Sci Technol 51(6):976-989

101. Butler CS, Debieux CM, Dridge EJ, Splatt P, Wright M (2012) Biomineralization of selenium by the selenate-respiring bacterium Thauera selenatis. Biochem Soc Trans 40(6):1239

102. Ansari AA, Gill SS, Gill R, Lanza GR, Newman L (2016) Phytoremediation. Springer, Berlin

103. Carvalho KM, Gallardo MT, McGettigan MJ, Martin DF (2000) Remediation of selenium contamination by plants and microbes: an annotated bibliography. Fla Sci 63:133-141
104. Newete SW, Erasmus BF, Weiersbye IM, Byrne MJ (2016) Sequestration of precious and pollutant metals in biomass of cultured water hyacinth (Eichhornia crassipes). Environ Sci Pollut Res Int 23(20):20805-20818

105. Banuelos G, Lin Z, Wu L, Terry N (2002) Phytoremediation of selenium-contaminated soils and waters: fundamentals and future prospects. Rev Environ Health 17(4):291-306

106. Hill CM (2010) Review of available technologies for the removal of selenium from water. Final Report, prepared for North American Metals Council (NAMC)

107. Ghosh-Dastidar A, Mahuli S, Agnihotri R, Fan LS (1996) Selenium capture using sorbent powders: mechanism of sorption by hydrated lime. Environ Sci Technol 30(2):447-452

108. Agnihotri R, Chauk S, Mahuli S, Fan LS (1998) Selenium removal using ca-based sorbents: reaction kinetics. Environ Sci Technol 32(12):1841-1846

109. Zhu L, Zhang L, Li J, Zhang D, Chen L, Sheng D, Yang S, Xiao C, Wang J, Chai Z (2017) Selenium sequestration in a cationic layered rare earth hydroxide: a combined batch experiments and EXAFS investigation. Environ Sci Technol 51(15):8606-8615

110. Kuroda $M$, Notaguchi E, Sato A, Yoshioka M, Hasegawa A, Kagami T, Narita T, Yamashita M, Sei K, Soda S, Ike M (2011) Characterization of Pseudomonas stutzeri NT-I capable of removing soluble selenium from the aqueous phase under aerobic conditions. J Biosci Bioeng 112(3):259-264

111. Kagami T, Narita T, Kuroda M, Notaguchi E, Yamashita M, Sei K, Soda S, Ike M (2013) Effective selenium volatilization under aerobic conditions and recovery from the aqueous phase by Pseudomonas stutzeri NT-I. Water Res 47(3):1361-1368 